Discussion Paper No. 09-012

Earnings of Men and Women in Firms with a Female Dominated Workforce

What Drives the

Impact of Sex Segregation on Wages?

Anja Heinze

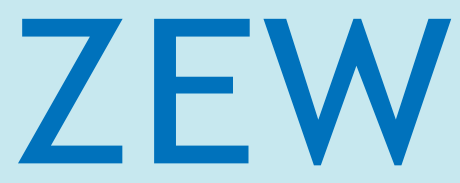

Zentrum für Europäische Wirtschaftsforschung $\mathrm{GmbH}$

Centre for European

Economic Research 


\title{
Discussion Paper No. 09-012 \\ Earnings of Men and Women in Firms with a Female Dominated Workforce \\ What Drives the \\ Impact of Sex Segregation on Wages?
}

\author{
Anja Heinze
}

Download this ZEW Discussion Paper from our ftp server:

ftp://ftp.zew.de/pub/zew-docs/dp/dp09012.pdf

Die Discussion Papers dienen einer möglichst schnellen Verbreitung von neueren Forschungsarbeiten des ZEW. Die Beiträge liegen in alleiniger Verantwortung der Autoren und stellen nicht notwendigerweise die Meinung des ZEW dar.

Discussion Papers are intended to make results of ZEW research promptly available to other economists in order to encourage discussion and suggestions for revisions. The authors are solely responsible for the contents which do not necessarily represent the opinion of the ZEW. 
Non-technical summary: International studies based on the linked employer-employee data (e.g. Carrington and Troske 1998 Reilly and Wirjanto 1999a, Amuedo-Dorantes and De la Rica 2006) find that both men and women receive lower wage rates in firms with a high female proportion of the workforce. This study considers this topic for Germany. The study also addresses the possible reasons for a correlation between the proportion of women in establishments and the pay earned by women and men.

The first hypothesis is that establishments with a high share of female employees offer attractive working conditions by, for example, reconciling the demands of work and family. On the basis of compensating wage differentials (Rosen 1986) the employees in such establishments tend to be paid lower wages.

The second hypothesis is based on two assumptions: Women are less well qualified than men and establishments are heterogeneous in terms of the qualification requirements of their employees. It is therefore assumed that establishments seeking low qualified individuals show a high proportion of women in their workforce and pay lower wages.

Another possible explanation discussed for the correlation between the proportion of women in establishments and the individual wage is the discrimination preference of the employer. In the framework of this third hypothesis, discriminatory employers are assumed to hire fewer women and to pay them lower wages, while men receive a preferential treatment and higher pay in such firms.

These hypotheses are systematically examined in the empirical analysis. In addition to the proportion of women in the establishment, various individual and establishment characteristics are included successively in the regression analysis as determinants of wages. Individual qualifications and workplace characteristics can be controlled for by drawing on the extensive information provided by the LIAB data.

The wage regressions - which, apart from the proportion of women in establishment workforces, only include human capital characteristics and occupation as explanatory variables - show different relationships for eastern and western Germany. In western Germany, the proportion of women in the workforce has a negative impact on the individual wages paid to men and women. In eastern Germany, in contrast, there appears to be no significant relationship between individual wages and the share of women in the workforce. If variables which describe workplace characteristics which appear to be particularly attractive for women are included, the impact of proportion of women in the firm workforce becomes less significant. Thus, there is empirical evidence that women themselves select firms which 
offer them an attractive working environment for which they are prepared to accept a reduction in pay. However, this effect is much weaker in eastern than in western Germany.

The second hypothesis is confirmed in part. The proportion of women in an establishment would appear to reflect the lower qualifications of women employees. Less well-qualified men do not select employment into female dominated firms. Nonetheless, men in femaledominated firms are less well paid than men working elsewhere.

The discrimination preferences of employers cannot directly be observed. This means that the third hypothesis can only be tested indirectly. After controlling for individual qualifications and establishment characteristics, the proportion of women in an establishment is shown to have a negative impact on the pay of men and women, thus partly contradicting the discrimination hypothesis. 
Das Wichtigste in Kürze: In internationalen Untersuchungen auf Basis von Linked EmployerEmployee Daten (z.B. Carrington und Troske 1998 Reilly und Wirjanto 1999a, AmuedoDorantes und De la Rica 2006) wird festgestellt, dass sowohl Männer als auch Frauen in Betrieben mit einem vergleichsweise hohen Frauenanteil in der Belegschaft einen geringeren Lohn erhalten als Beschäftigte in männerdominierter Betrieben. Mit dieser Thematik auf Deutschland bezogen beschäftigt sich die vorliegende Studie. Darüber hinaus wird aber auch der Frage nachgegangen, welche Ursachen es für eine Korrelation zwischen dem Frauenanteil innerhalb von Unternehmen und den individuellen Löhnen von Frauen und Männern gibt.

Die erste Hypothese basiert auf der Annahme, dass Betriebe mit einem hohen Frauenanteil gerade weiblichen Beschäftigten attraktive Arbeitsbedingungen bieten, indem sie beispielsweise die Vereinbarkeit von Beruf und Familie unterstützen. Auf Basis kompensierender Lohndifferentiale (vgl. Rosen 1986) erhalten die Beschäftigen in solchen Unternehmen einen tendenziell geringeren Lohn.

Die zweite Hypothese basiert auf zwei Annahmen: Frauen sind weniger qualifiziert als Männer und Betriebe sind heterogen bzgl. der Qualifikationsanforderungen an ihre Beschäftigten. Es wird demzufolge vermutet, dass Firmen mit einem hohen Frauenanteil niedrig qualifizierte Beschäftigte nachfragen und sie infolgedessen geringer entlohnen.

Als weitere mögliche Erklärung für die Korrelation zwischen dem Frauenanteil innerhalb von Betrieben und dem individuellen Lohn werden Diskriminierungspräferenzen von Seiten der Arbeitgeber diskutiert. Im Rahmen dieser Hypothese wird angenommen, dass diskriminierende Arbeitgeber weniger Frauen einstellen und diesen einen geringeren Lohn zahlen, während Männer in solchen Firmen bevorzugt eingestellt werden und einen höheren Lohn enthalten.

In der empirischen Analyse werden die aufgestellten Hypothesen systematisch überprüft. Dabei werden sukzessive verschiedene individuelle und firmenspezifische Merkmale neben dem Frauenanteil innerhalb von Betrieben als Lohndeterminanten in der Regressionsanalyse aufgenommen. Die umfangreichen Informationen der LIAB-Daten ermöglichen es, für die individuelle Qualifikation und Arbeitsplatzcharakterisitika zu kontrollieren.

In die Lohnregressionen, in die neben dem Frauenanteil innerhalb von Firmen nur individuelle Humankapitalmerkmale und der Beruf als erklärende Variable aufgenommen werden, zeigen sich für Ost- und Westdeutschland unterschiedliche Zusammenhänge. In Westdeutschland ergibt sich ein negativer Effekt des Frauenanteils auf den individuellen Lohn bei Männern und Frauen. In Ostdeutschland hingegen zeigt sich zunächst kein signifikanter Zusammenhang zwischen dem individuellen Lohn und dem Frauenanteil. Bei der Aufnahme 
von Variablen, die Arbeitsplatzmerkmale beschreiben, die besonders attraktiv für Frauen erscheinen, sinkt der Einfluss des Frauenanteils innerhalb von Firmen. Damit zeigt sich empirische Evidenz dafür, dass sich Frauen in Firmen selektieren, die eine für sie angenehme Arbeitsumgebung schaffen und für die sie bereit sind, Lohnabschläge in Kauf zu nehmen. In Ostdeutschland ist dieser Effekt allerdings weit aus schwächer als in Westdeutschland.

Die zweite Hypothese wird zum Teil bestätigt. Anscheinend reflektiert der Frauenanteil innerhalb von Firmen die geringere Qualifikation von weiblichen Beschäftigten. Gering qualifizierte Männer selektieren sich nicht in frauendominierte Firmen. Trotzdem werden Männer in frauendominierten Firmen geringer entlohnt als Männer in nicht frauendominierten Firmen.

Diskriminierungspräferenzen von Arbeitgebern können nicht beobachtet werden. Daher kann die dritte Hypothese nur indirekt getestet werden. Nachdem für individuelle Qualifikation und Firmenmerkmale kontrolliert wird, zeigt sich sowohl für Männer als auch für Frauen, dass der Effekt des Frauenanteils innerhalb von Firmen auf den Lohn negativ ist. Die dritte Hypothese wird somit durch diese empirische Studie nicht unterstützt. 


\title{
Earnings of men and women in firms with a female dominated workforce
}

\author{
What drives the impact of sex segregation on wages?
}

\author{
Anja Heinze \\ Centre for European Economic Research (ZEW Mannheim) *
}

\begin{abstract}
This study analyzes the relationship between the segregation of women across establishments and the salaries paid to men and women. My aim is to separate the impact the proportion of women working within an establishment has upon individual wages. For this purpose hypotheses are formulated as to what drives this impact: sex-specific preferences, lower qualifications among women or discrimination against women. To investigate this issue empirically, I use matched employer-employee data from Germany. My results indicate that an increasing proportion of women in an establishment reduces wages for males and females in both western and eastern Germany. Furthermore the empirical analysis shows that by successively including worker and establishment characteristics, the number of females in an establishment has a severely detrimental effect upon the salaries paid to both sexes.
\end{abstract}

JEL Classification: J16, J31, J71

Keywords: gender wage differentials, female segregation across establishments, matched employer-employee data

\footnotetext{
* Centre for European Economic Research, Department of Labor Markets, Human Resources and Social Policy, L7.1, 68161 Mannheim, Germany, E-Mail: heinze@zew.de. I would like to thank Michael Burda, Bernd Fitzenberger, Alfred Garloff, Nicole Gürtzgen, Melanie Arntz and participants of Fitzenberger's doctoral workshop for valuable comments and discussions. I am grateful to Peter Jacobebbinghaus and Dirk Oberschachtsiek for help with the data at the Research Data Centre (FDZ) of the Federal Employment Services (BA) at the Institute for Employment Research (IAB), Nuremberg. The institutions mentioned are not responsible for the use of the data in this publication. The financial support by the German Research Foundation (DFG) within the priority program "Potentials for Flexibility in Heterogeneous Labor Markets" (Grant-No. PF 331/3-1) is gratefully acknowledged.
} 


\section{Introduction}

The fact that women earn lower wages than men has been documented in many studies for several countries and periods of time. One important result of this research is that there is a relationship between the wages of men and women and the gender composition of occupations, industries and firms ${ }^{1}$. Such evidence helps to understand the source of gender differences and could potentially increase the effectiveness of policies that aim to reduce the gender wage gap.

Most segregation research has focused on the impact of occupational segregation of men and women on the gender wage gap (e.g. Macpherson and Hirsch 1995) and the effect of industry segregation (e.g. Fields and Wolff 1995). The empirical studies show that individual wages vary systematically according to the gender composition of occupations and industries. More precisely, an increasing proportion of women has a detrimental effect upon the wages of men and women.

The relationship between wages and sex segregation at establishment level has been studied less in empirical analysis. ${ }^{2}$ The first studies (McNulty 1967, Buckley 1971, Blau 1977) found that women were more likely to work in lower paying firms than men. More recent investigations (e.g. Carrington and Troske 1998, Reilly and Wirjanto 1999a, Bayard et al. 2003, Vieira et al. 2005, Amuedo-Dorantes and De la Rica 2006) support this result and demonstrate that the individual wages of men and women decrease as the proportion of women within an establishment increases.

However, most empirical studies do not sufficiently scrutinize the measured impact of the proportion of females within establishments on individual wages. For this reason, I shall attempt to go one step further in my analysis. Why should sex segregation at establishment level impact upon individual earnings? I examine three hypotheses. Firstly, by assuming gender differences in the preferences for specific establishment and workplace characteristics, the proportion of females in an establishment may reflect the attractiveness of a specific workplace environment for women, creating an environment in return for which they are willing to accept lower wages. Secondly, I examine the so-called quality sorting hypothesis, which considers the proportion of females within an establishment as a proxy for the skill requirements of the employer. The main assumptions are that skill requirements

\footnotetext{
${ }^{1}$ In the study the terms firm and establishment are used synonymously.

${ }^{2}$ One reason is the lack of micro-data with information on both the employers and employees. Indeed, the availability of linked employer-employee data in the last decade has generated many studies which highlights firm aspects. For a survey of linked employer-employee data see e.g. Abowd and Kramarz (1999)
} 
vary from establishment to establishment and that men and women have different skill endowments, with the latter being less well-qualified. Finally, another possible explanation for a connection between the proportion of females within establishments and individual wages could be discriminatory preferences among employers against women. In this study, I investigate the direction of the relationship between the proportion of females within establishments and the wages of male and female employees by specifying various wage equations for both western and eastern Germany. For this purpose, I use a rich linked employer-employee data set maintained by the Research Data Centre of the Federal Employment Agency at the Institute for Employment Research in Germany. This data set is rich in terms of information on important productivity-related characteristics (e.g. education and tenure) and very detailed information on establishment characteristics (e.g. employment number, collective bargaining and industry). A further strength of this data is that the available number of observations is very large ${ }^{3}$, making it possible to obtain reliable estimates for the parameters of interest.

By means of this analysis, I attempt to investigate why sex segregation affects individual earnings. Such an improved understanding is important for designing adequate policies. If the reason for a negative relationship between the proportion of females and individual wage rates arises from the choice of women to work for firms that provide an attractive working environment for them, such policies will differ from policies aiming at reducing discrimination against women. In the latter case, one can initiate the discussion about affirmative action or employment equity programs to address issues of imbalance in the sex composition of establishments. If the impact of the proportion of females within establishments on individual wages is due to self-selection of women in certain firms, then there is no need for direct political intervention at firm level. If the relationship between the proportion of females within an establishment and the level of wages paid can be attributed to lower qualifications among women, then policies should aim to improve qualifications among women.

In this study, I will not address occupational segregation even though occupation is a very interesting dimension. Occupational segregation is more constant over time than segregation at firm level because occupational changes occur less often. Nonetheless, I refrain from including occupational segregation as many empirical studies measuring the impact of

\footnotetext{
${ }^{3}$ The data set contains a representative sample of German establishments with at least one employee covered by the German social security system and all employees in these establishments who pay social security contributions.
} 
occupational segregation on wages have already been conducted. For instance, Achatz et al. (2005) as well as Jurajda and Harmgart (2007) have investigated this issue as it affects Germany.

The study will then develop thus. In the following section, I present a brief review of the empirical literature that investigates the relationship between the gender composition in establishments and individual wages. In Section 3, I formulate hypotheses that seek to explain the relationship between sex segregation and the wages of women and men. In Section 4, I describe the empirical methodology that I employ to gauge this relationship. In the subsequent section, I introduce the data set and provide descriptive statistics of the characteristics. The results of the estimations are presented in Section 6. The Section 7 provides a conclusion.

\section{Previous empirical literature}

In this section I will summarize the results of previous empirical studies that analyze the association between the proportion of females in establishments and wages. I will focus on studies that use establishment level data. ${ }^{4}$

The first empirical studies investigating earnings and gender segregation at establishment level emerged in the seventies. McNulty (1967) and Buckley (1971) indicate that inter-firm gender segregation is an important factor for determining different earnings of male and female employees. Both studies point out that men tend to work in high-wage establishments and women in low-paying establishments. Using the same data set for the US they compare average wages of male and female employees between integrated and single-sex establishments by occupations. The comparison reveals that men's earnings exceed those of women in the same occupations but these differences are smaller in establishments employing both sexes. However, the descriptive results are derived from selected occupational earnings and establishments. Blau (1977) also considers selected occupational groups in three metropolitan statistical area but she exploit the information to the accurate proportion of female employees within firms. She computes the correlation between the ranking of firms with respect to both wages and the proportion of female employees. This ranking is based on coefficients associated with firm dummies in two separate regressions on wages and the proportion of female employees, respectively. The negative estimated correlation coefficient suggests that females are highly presented in the workforce in firms

${ }^{4}$ c. f. Foguel (2004) 
which pay lower wages to both sexes, while males comprise a higher proportion of employees in those firms which pay higher wages.

Groshen (1991a) extends the work of Blau (1977) by jointly estimating the effects of segregation by occupation, establishment and job-cells ${ }^{5}$ on the wages of workers within five industries in the US. Her results show a negative relationship between gender segregation at establishment level and individual wages in all five industries. Furthermore, it seems that in some industries gender segregation at establishment level explained the gender wage gap for the most part, while in other industries occupational segregation is more important in determining the gap. The used data set, however, does not include further information on employees and establishments. Hence, typical wage determinants such as education and experience are not taken into account, which are presumably important controls in gender wage regressions.

Carrington and Troske (1995) study the establishment gender segregation in small U.S. firms. In an establishment level regression they estimate the impact of the proportion of women on the average wage within an establishment (wage bill per employee). The estimates reveal that firms with a predominantly male workforce tend to pay higher average wages than firms where women account for the majority of the workforce. In a follow-up study Carrington and Troske (1998) improve their previous work by using individual worker information from a small sample of linked employer-employee data. In a pooled wage equation for male and female employees they control for various worker and establishment characteristics and use an interaction term between the female dummy and the proportion of women within an establishment variable to ascertain the impact of gender segregation on female and male wages. The basic findings are that both men and women earn less in firms that are predominantly staffed by women, but that the negative effects experienced by women are greater.

Bayard et al. (2003) attempt to review the results of Groshen (1991a) by a using comprehensive matched employer-employee data set which covers all industries and occupations across all regions in the US. They also find negative effects arising from the proportion of females within an establishment on wages for both sexes. This negative impact is again greater for women. Their results also indicate that, even though a sizeable part of the gender wage gap can be explained by the segregation of females into lower-paying occupations, industries, establishments and job cells, a considerable part of the gap remains unexplained. These findings differ from other research, most notably that of Groshen

\footnotetext{
${ }^{5}$ Job-cells mean the interaction between occupations and establishments.
} 
(1991a). The authors attribute the deviations to the larger data set and to the inclusion of some controls for individual characteristics and industry dummies in separate regressions for men and women.

The European studies conducted by Datta Gupta and Rothstein (2005) as well as AmuedoDorantes and De la Rica (2006) are similar to those of Groshen (1991a) and Bayard et al. (2003). Datta Gupta and Rothstein (2005) use matched employer-employee data from Denmark to investigate how gender segregation affects the gender wage gap, while AmuedoDorantes and De la Rica (2006) focus on Spain. Both analyses estimate pooled (by gender) wage equations that include the proportion of females in industry, occupation, establishment and job-cell. The relationship between the proportion of females within firms and individual wages is negative. In addition, in separate wage regressions by gender, Amuedo-Dorantes and De la Rica (2006) find that being employed in a predominantly female establishment has a negligible impact on men's wages, whereas it significantly reduces female wages. In both studies the authors focus on the effect of segregation on the wage gap (rather than on individual earnings) and find that there is a significant within-job-cell gender wage differential.

Reilly and Wirjanto (1999a) investigate the relationship between wages and gender segregation for Canada with a small sample of matched employer-employee data. In a Generalised Least Squares (GLS) regression framework they find that the proportion of women in an establishment has a negative impact on individual wages for both men and women. Again the negative effect on the female wages is more pronounced than on male wages.

Vieira et al. (2005) study gender segregation at the establishment level over fifteen years in Portugal, and its impact on wages and the gender wage gap by using a large matched employer-employee data set. This is the only study that finds a negative effect arising from the proportion of women within firms on women's wages and, on the contrary, a positive effect on men's wages.

In an empirical analysis, Achatz et al. (2005) use one wave (from the year 2000) of a German linked employer-employee data set (the LIAB data) to investigate the impact of the proportion of females within job-cells on individual wages in western Germany. Like most other studies, they find that the negative relationship is more pronounced for women. They conclude that discrimination occurs particularly through a gender-based assignment of jobs. In summary, previous empirical studies lead one to conclude that working in establishments with a predominantly female workforce reduces wages for both sexes, with this effect being 
more pronounced for women. Despite a consensus regarding these stylized facts, the magnitude and interpretation of the relationship between wages and gender composition remain unclear. ${ }^{6}$ In this study, I attempt to investigate the relationship between the proportion of females within establishments and individual wages by including individual characteristics such as experience, education and occupation as well as standard firmspecific variables such as establishment size and type of industry. In an extension to previous studies, I attempt to control for further establishment characteristics by exploiting the rich firm-side of my data set. If firm characteristics are important, including them should reduce the impact of the proportion of females within establishments on individual wages. In this way, I seek to understand what is measured by the impact of the proportion of females on individual wages.

\section{Theoretical framework}

In this section I present three hypotheses which deal with the gender wage gap and sex segregation at establishment level. I begin by reviewing the hypothesis that gender differences in wages and employment patterns are the consequence of preferences. I then go on to formulate a second hypothesis that is based on skill differences between men and women. I then present a third hypothesis that explains the relationship between the proportion of females within firms and wages by assuming that discriminatory attitudes are adopted by employers against women.

\subsection{Preference hypothesis}

The role of differences in preferences is often emphasized in the discussion of gendered labor market outcomes. Men and women are assumed to differ in their preferences for market versus non-market work or leisure as well as for particular types of work, such as manual labor versus office work. ${ }^{7}$ The distribution of preferences for particular job attributes among men and women and the costs to employers of offering jobs with particular characteristics will affect the wage distribution. For instance, the theory of compensating differentials (Rosen 1986) predicts that if differences in job characteristics, such as inflexible

\footnotetext{
${ }^{6}$ Some studies hastily explain the negative impact by discrimination.

${ }^{7}$ Related to the topic is the question concerning the source of gender differences in preferences (see Altonji and Blank 1999). There is only little direct evidence concerning the question how and why preferences might develop over time. For instance, the differential treatment of boys versus girls in the family or in the educational system may be one source of differences in preferences. However, regardless of the source, in a competitive labor market gender differences in preferences can imply gender differences in labor force participation, in workplaces and in wages.
} 
work schedules or shift work, are associated with a disutility, then such jobs will offer a wage premium. The theory further predicts that those workers with a relatively high tolerance for such disamenities will naturally gravitate towards these jobs. If workers with these preferences are also predominantly males, then such jobs will be largely filled by men. The argumentation of the theory of compensating differentials can be used to explain the negative correlation between the proportion of females within firms and the wages of both males and females. Firms differ regarding the technologies used in production, the institutional background, the profit situation and so on. Hence, they offer jobs with different characteristics. On the other hand, there are certain job characteristics which are typically favored by women and which are connected to lower wage rates. These are mainly job characteristics which improve the work-life balance as the major burden of family work is still borne by women. These attributes are, for instance, flexible working time, less overtime, a firm kindergarten or crèche, or special mentoring programs for female employees. The workplace attributes are connected with costs for the employers and thus lead to a wage reduction, which is likely to be accepted by those individuals with a greater preference for these workplace amenities ${ }^{8}$. Based on the assumption that women have a greater preference for these characteristics, firms offering these attributes will be particularly attractive for women. This results in a larger proportion of female employees than in establishments not offering such benefits. These considerations show that if one does not control for an attractive working environment in a wage regression analysis, the impact of the proportion of females in establishments on wages is likely to reflect part of the negative correlation between certain job characteristics and individual wages. This also holds true for men: Men choosing to work for firms with a predominately female workforce also seems to be willing to accept lower wages for job characteristics such as flexible working hours.

Reilly and Wirjanto (1999b) argue in a similar manner. In their study they employ the expression “coincidence of needs”. They argue that firms with a high proportion of females offer employment contracts to employees that fit the employment pattern preferred by women. Worker and employers have preferences, technological choices, and constraints that have to correspond. A successful job match is thus a coincidence of needs. That implies the sorting of women into specific establishments. The resulting (compensating) wage differential reflects the mutually advantageous trade between employers and employees.

\footnotetext{
${ }^{8}$ The costs are partly transferred from employers to employees and the resulting wage reduction depends on the bargaining power of employees and employers.
} 


\subsection{Qualification hypothesis}

The second hypothesis dealing with the relationship between individual wages and sex segregation at establishment level is related to the so-called quality sorting hypothesis, which finds frequent mention in the literature (see e.g. Macpherson and Hirsch 1995, Carrington and Troske 1998, Reilly and Wirjanto 1999a). The idea is simple and based on two premises. The first is that firms are heterogeneous in terms of the skill demands on employees. Some establishments need many highly qualified workers for their production. These would include such establishments as research establishments. Other firms, for example cleaning companies, demand low skilled workers. The second premise is that women and men have different skill levels, with the former group being less qualified. The lower qualification of women is often explained by the human capital model (e.g. Mincer and Polachek 1974). This model departs from the traditional gender division of labor within families under which women are expected to have a shorter and more intermittent attachment to the labor market than men. This implies, ceteris paribus, that the net return on pre-labor market investments in human capital for women will be lower than that for men. Similarly, the shorter and more discontinuous labor force participation of women reduces the long-run pay-off on investments in general and firm-specific training. Thus, given their shorter expected working life, women's optimal response is to acquire a lower amount of human capital in terms of training and labor market experience. Polachek (1981) also argued that women invest rather in human capital and favor occupations with lower rates of depreciations for periods of absence from the labor force.

The result of the two premises is that firms requiring relatively more unskilled (skilled) labor will have a higher (lower) concentration of females and pay lower (higher) wages. According to the quality sorting hypothesis, male employees in firms with a predominantly female workforce are also less well-qualified than men in other firms. Thus, in the quality sorting hypothesis the gender composition of a firm serves as an index of labor quality. This hypothesis therefore predicts that wages of men and women are negatively correlated with the proportion of females in the establishment if one does not control for productivity.

Note that in the quality sorting hypothesis mentioned in literature (see e.g. Hirsch and Schumacher 1992, Macpherson and Hirsch 1995, Hirsch and Macpherson 2004) ${ }^{9}$, the proportion of female employees is assumed to be correlated to both measured and unmeasured labor productivity differences. Here, I can only control for observed

\footnotetext{
${ }^{9}$ However, the first two mentioned studies investigate wages and racial composition.
} 
characteristics. To the extent that measurable and immeasurable labor quality factors are positively correlated, this may partly cover unobserved differences.

\subsection{Discrimination hypothesis}

The third hypothesis is framed by the Becker (1971) model of employer discrimination. I shall explain this model in more detail since it is less straightforward than the two hypotheses already dealt with. Following this model, a wage-taking firm with a production function $f$ uses two inputs: the labor of men, $M$, and labor of women, $F$, which are perfect substitutes ${ }^{10}$. Employers have a dislike of hiring female workers, and do not maximize profits but rather maximize utility, defined as

$$
U(\pi, M, F)=Y(M+F)-w_{M} M-w_{F} F-d \cdot(F / M)
$$

where $d$ is the discrimination coefficient representing this dislike, $w_{M}$ and $w_{F}$ are the market wages of men and women respectively. ${ }^{11}$ Short-run utility maximization then implies

$$
M P_{M}+d\left(F / M^{2}\right)=w_{M}, \quad M P_{F}-d / M=w_{F} .
$$

The marginal product of male labor $M P_{M}$ is below its input price $w_{M}$, because male labor increases the employer's utility, the marginal product of female labor $M P_{F}$ is discounted by the non-pecuniary cost of discrimination to the employer and hence is above the input price of female labor $w_{F}$. The discrimination coefficient $d$ will lead the firm in the short run to hire fewer women and more men than profit maximization would dictate. ${ }^{12}$ The degree of aversion to hiring female employees is assumed to vary across employers. Firms with weaker discriminatory preferences (smaller $d$ ) will tend to hire relatively more women and relatively fewer men, and vice versa. Thus, preferences provide the exogenous source of variation in the proportion of females across otherwise identical firms. However, in the Becker model the firms are price-takers, so the wages for male and female employees do not vary across firms. Another drawback of the model is that employer discrimination cannot persist under perfect competition without productivity differences between male and female

\footnotetext{
${ }^{10}$ Perfect substitutes imply that male and female employees have the same marginal product of labor, $M P_{M}=M P_{F}$

${ }^{11}$ The output price is standardized to 1 .

${ }^{12}$ Arrow (1973) formulated it in this way. In the original model $d$ simply multiplies $F$ in the employer's utility function, which generates complete sex segregation across the board with the exception of the marginal employer. The utility function based on the relative number of female employees leads to an equilibrium less at odds with observed employment patterns.
} 
employees. Firms which have no aversion to hiring women pay wages according to their marginal productivity and force the discriminatory firms out of the market. Thus the assumption of perfect competition is relaxed towards that firms have monopsony power.

The new monopsony literature emphasizes that monopsony power may even occur if there are many employers competing for employees, and not only in the case of one single employer (see for a systematic presentation of this literature Manning 2003). Models of new monopsony literature ascribe upward-sloping firm level labor supply curves ${ }^{13}$ to mobility costs, search frictions and heterogeneous preferences among employees. ${ }^{14}$ Discrimination against women in a situation of such imperfect competition results in lower wages and a reduced level of employment for women. In order to demonstrate this, it is supposed that the firm level labor supply curve of men and women is equal to $L^{s}\left(w_{g}\right), g=M, F{ }^{15}$ The male and female employees are perfect substitutes in production. If the employer dislikes employing women, the utility function ${ }^{16}$ has the following form:

$$
U=Y\left(L^{s}\left(w_{M}\right)+L^{s}\left(w_{F}\right)\right)-w_{M} L^{s}\left(w_{M}\right)-w_{F} L^{s}\left(w_{M}\right)-d L^{s}\left(w_{F}\right) .
$$

By differentiating equation (3) with respect to $w_{M}$ and $w_{F}$, the optimal wage rates for men and woman can be obtained. They are as follows:

$$
\begin{aligned}
& w_{g}^{*}=\frac{\varepsilon\left(w_{g}^{*}\right)}{1+\varepsilon\left(w_{g}^{*}\right)}\left(M P_{g}-d_{g}\right) \\
& \text { with } \varepsilon\left(w_{g}\right)=\frac{w_{g} L^{S}\left(w_{g}\right)}{L^{s}\left(w_{g}\right)} \text { and } d_{g}= \begin{cases}d>0 & \text { if } g=F \\
0 & \text { if } g=M\end{cases}
\end{aligned}
$$

where $\varepsilon(w)$ denotes the elasticity of the labor supply and lies between 0 and $1, w_{g}^{*}$ is the wage for male and female employees, $g=M, F$, given the labor supply curve. If the

\footnotetext{
${ }^{13}$ The analyses of job-to-job flows within a search framework by Burdett and Mortensen (1998) and Manning (1994) have established the idea that each single firm or establishment faces its own individual labor supply curve. The point is that workers quit endogenously, and have to be replaced by new hires. The higher the wage, the lower the number quitting and thus the easier it is to attract replacement hires.

${ }^{14}$ Bergmann (1974) argued in a related way in her "overcrowding” model. She acts on the assumption that men and women are segregated into two occupations. Furthermore, it is assumed that there is no mobility of labor between occupations. Hence, if the job opportunities for women are small relative to their labor supply, women will "crowd" to work in one occupation. This depresses the wage there. This results in a gender wage differential. The argumentation is often mentioned in studies dealing with occupational segregation. However, the segregation is exogenously given in that model framework.

${ }^{15}$ I suppress the firm subscript.

${ }^{16}$ Note, for simplification I return to the original formulation of the Becker model assuming that the utility negatively depends on the number of the hired women instead of the relative number. Using the relative number of female employees would unnecessarily complicate the analysis. Then the derivations of the utility regarding the male and female wages would also depend on the labor supply of the other gender. Thus I cannot formulate a clear relationship as an equation (4).
} 
second-order condition is satisfied, $L^{s} "-2\left(L^{s}\right)^{2}<0$, and one can see that women obtain a lower wage than male employees. Wages and employment therefore are both lower for women. This result would be even stronger if one assumes that the female labor supply is more inelastic than its male counterpart. ${ }^{17}$

Thus the preference-based discrimination model predicts that the proportion of female employees varies across firm depending on the degree of discriminatory behavior: the less (more) discriminatory the employer is, the higher (lower) the proportion of women in the firm. In addition, the monopson model framework allows employers a wage setting policy according to the firm-specific elasticity of labor supply and to the extent of aversion to employing women. Ceteris paribus, the wage rate of female employees decreases with the degree of discrimination. Thus, supposing the same wage elasticities for male and female employees, the formulated discrimination hypothesis predicts a positive relationship between wage rates of female employees and the proportion of women within an establishment when the latter is a proxy for the disinclination to employ women. In contrast to this, the hypothesis predicts a negative relationship for male employees. This directly results from the upward-sloping labor supply, predicting a lower employment level for the group that receives a lower wage.

Note, in this hypothesis I use the preference-based discrimination model according to Becker (1971) and Arrow (1973) respectively. This model is embedded in a monopsony framework to derive a relationship between individual wages and the proportion of females which varies across establishments.

To sum up, the first two hypotheses, the preference and qualification hypotheses, both predict a negative relationship between the proportion of females within establishments and individual wages for both male and female employees. The discrimination hypothesis predicts a positive relationship between the proportion of females and wages for women and a negative relationship for men.

In the empirical analysis I want to investigate what drives the impact of the proportion of females within establishments on individual wages. By successively including productivityrelated characteristics and variables describing the workplace I extract the impact of those

\footnotetext{
${ }^{17}$ This is the idea of monopsonistic discrimination in the labor market developed by Robinson (1933). In this model it is assumed that the female labor supply is more inelastic than the male labor supply. Thus women will earn less than men relative to their productivity, and thus face a higher level of exploitation in the labor market. In this model framework the existence of gender pay gap can be explained by difference in labor supply between men and women even if employers have no discrimination preferences. Ransom and Oaxaca (2005) and Hirsch et al. (2006) empirically support the idea that female labor supply to the firm is less elastic than male labor supply.
} 
variables from the effect of the proportion of females. Thus I can directly test my first two hypotheses.

Unfortunately I cannot directly test the discrimination hypothesis because I cannot observe the discriminatory behavior of employers. However, if I can rule out that the proportion of females reflects preferences and productivity differences, the explanation is likely to be discrimination. Thus I can indirectly test the discrimination hypothesis by controlling for productivity-related characteristics and variables describing the workplace. I check whether the remaining effect of the proportion of females on wages is in accordance with the predicted relationship in the discrimination hypothesis.

\section{Empirical methodology}

In order to analyze the effect of the proportion of females within an establishment on the wages of individuals I consider a standard censored Tobit model since the dependent variable is censored from above in the used data set (see next section):

$$
\begin{aligned}
w_{i j}^{g *} & =\beta^{g} X_{i j}^{g}+\gamma^{g} \phi_{j}^{g}+\varepsilon_{i j}^{g} \quad i=1, \ldots N_{j}, j=1, \ldots J \\
w_{i j}^{g} & =c \text { if } w_{i j}^{g *} \geq c \\
w_{i j}^{g} & =w_{i j}^{g *}=\beta^{g} X_{i j}^{g}+\gamma^{g} \phi_{j}^{g}+\varepsilon_{i j}^{g} \text { if } w_{i j}^{g *}<c \\
\varepsilon_{i j}^{g} & \sim N\left(0, \sigma_{j}^{g}\right)
\end{aligned}
$$

where superscript $g=(m, f)$ indicates the gender, $w_{i j}^{g}$ describes the observed log wage of worker $i$ in establishment $j, w_{i j}^{g *}$ refers to the actual log wage, $X_{i j}^{g}$ denotes a various set of individual and job related characteristics dependent of the specification, $\phi_{j}^{g}$ presents the proportion of females in the establishment. Furthermore $\beta^{g}$ and $\gamma^{g}$ are the corresponding regression coefficients, $\varepsilon_{i j}^{g}$ is an error term and $\sigma_{j}^{g}$ is the establishment-specific variance of these. The right-censoring of the dependent variable can be dealt with by estimating a Tobit model, where the distribution of the log wage rate is censored from above at the point $c$ (the daily social security threshold).

I estimate the Tobit model (5) with robust parameter standard errors based on clusters at the establishment level. As I mentioned above, I use matched employer-employee data. For each establishment I observe wage rates of almost all employees. ${ }^{18}$ The standard regression assumption is that what is not known about the determination of wages is distributed

\footnotetext{
${ }^{18}$ I do not observe all workers because the data set includes only employees which are covered by the social security system (see next section). I also do not use all observable wage rates because of my sample selection. In the next section I describe these details.
} 
independently across all observations. This is an extremely strong assumption for this type of data. It is not reasonable to assume that establishments will set an individual's wage independently relative to other individuals in the firm. For instance, establishments might use internal labor markets to determine wages. This and other possible arguments suggest a non-independence of wage equation error terms for individuals who work in the same establishment.

This is the reason for using robust standard errors based on clusters at establishment level. I assume the following structure for the covariance of the errors:

$$
\sigma_{i k j}= \begin{cases}\sigma_{i k j} & \text { for } i \neq k, j=l ; i, k=1, \ldots, N_{j}, j, l=1, \ldots, J \\ \sigma_{j l}^{2} & \text { for } i=k, j=l ; i, k=1, \ldots, N_{j}, j, l=1, \ldots, J \\ 0 & \text { for } j \neq l ; i, k=1, \ldots, N_{j}, j, l=1, \ldots, J\end{cases}
$$

\section{Data}

In the empirical analysis I use data from the IAB Linked Employer-Employee panel (LIAB) which combines data from the IAB Establishment Panel and the Employment Statistics Register.

The IAB Establishment Panel is an annual survey of German establishments, which started in western Germany in 1993 and was extended to eastern Germany in $1996 .{ }^{19}$ The sample of selected establishments is random and stratified by industries, establishment size classifications and regions. The sample unit is the establishment as the local business unit. The establishments asked in the survey are selected from the parent sample of all German establishments that employ at least one employee covered by social security. Thus, the selfemployed and establishments employing only people not covered by social security (mineworkers, farmers, artists, journalists, etc.) as well as the public sector employing exclusively civil servants do not belong to the original sample. The data set is a representative sample of German establishments employing at least one employee who pays social security contributions. The establishments covered by the survey have been questioned every year about turnover, number of employees, composition of the workforce, personnel problems, industrial relations, wage policies, investments, innovations and business strategies.

The worker information comes from the Employment Statistics Register. This is an administrative panel data set of all employees in Germany paying social security

\footnotetext{
${ }^{19}$ Detailed information on the IAB Establishment Panel is given by Kölling (2000).
} 
contributions. $^{20}$ The data is based on notifications which employers are obliged to provide for each employee covered by the German social security system. According to the statutory provisions, employers have to report information for all employed contributors at the beginning and end of their employment spell. In addition an annual report for each employee is compulsory at the end of the year. This report contains information on an employee's occupation, the occupational status, qualification, sex, age, nationality and industry. Also the available information on daily gross earnings refers to employment spell that employers report to the Federal Employment Service. ${ }^{21}$ If the wage rate exceeds the social security threshold ("Beitragsbemessungsgrenze”), the daily social security threshold is reported instead. Note that the daily wage rate is therefore censored from above - mostly relevant for men.

Both data sets contain a unique establishment identifier which is used to match information on all employees paying social security contributions with the establishment in the IAB Establishment Panel.

I construct my sample in two steps. First I select establishments from the IAB Establishment Panel data set. I use the wave 2002 because it includes very interesting information describing the workplace. As mentioned in Section 3, the theoretical approaches are based on the profit-maximizing behavior of establishments. For this reason, I exclude observations corresponding to non-profit establishments, including the public sector. Since I implement separate analyses for eastern and western Germany I also construct separate data sets, whereby the location of the establishment determines the assignment.

In the second step, I merge the establishment data with notifications for all employees employed by selected establishments in the year 2002. From the worker data I drop observations for apprentices, part-time workers and home workers. I consider only full-time workers because the Employment Statistics Register lacks explicit information on hours worked. $^{22}$ To avoid modeling human capital formation and retirement decisions, I focus on individuals aged between 25 and 55 years. Some individuals in the data set have more than one job at the same time. Furthermore I select the observations that correspond to the main job of the individual to avoid that estimation with information on secondary labor market activities and notification errors are contaminated.

\footnotetext{
${ }^{20}$ Information on the Employment Statistics Register is given by Bender et al. (2000).

${ }^{21}$ To deal with the problem of overlapping spells, I apply a hierarchical order of activities where employment trumps all other activities.

${ }^{22}$ However, I have in mind that the meaning of my results is limited to full-time employed males and females although a lot of women work part-time.
} 
The final western German sample comprises 757,914 individuals in 6,123 establishments. The sample for eastern Germany contains 196,325 employees in 3,386 establishments.

The individual data contain information on the gross daily wage, age, gender, nationality, employment status, educational status ${ }^{23}$ and on the date of entry into the establishment. The latter is used to calculate tenure by subtracting the entry date from the ending date of the employer's notification which is also included in the data. Note, however, that this tenure variable cannot be corrected for employment breaks as this information is not available. Hence this variable is only a proxy for tenure.

The dependent variable in my empirical analysis is the real gross daily wage. The wage also includes such fringe benefits which are subject to social security contributions. The reported wage rates are top-coded at the upper contribution limit to the social security system. In my two samples, top-coding affects 17.66 percent of the observations from western Germany and 8.69 percent of those from eastern Germany. As can be seen in Tables A1 and A2 in the appendix, both in western and eastern Germany, male employees are more affected by topcoding than female employees.

Tables A1 and A2 provide descriptive statistics for the individual characteristics I use in the estimation. Row 1 reports the observed average log wage for male and female employees. A simple estimation of a wage equation for male and female employees by a Tobit model including a constant and a female dummy shows a substantial wage gap between sexes in western Germany ${ }^{24}$ : The average log wage of female employees is 20.57 percent lower than for male employees. At only 7.79 percent the average gender wage gap is significantly lower in eastern Germany. ${ }^{25}$ It is also interesting to see in Table A2 that in eastern Germany there are little differences between the human capital of male and female employees. That means, there are only small differences between average job tenures and educational attainments between the sexes (with women actually enjoying a slight advantage). In western Germany the differences are more pronounced (see Table A1 in the appendix).

I would now like to address the establishment variables described in Tables A3 and A4 in the appendix. The main variable used in the subsequent empirical analysis is the proportion of female employees in an establishment. Since I have information on all employed

\footnotetext{
${ }^{23}$ The six categories (no degree, vocational training degree, high-school degree, high-school degree and vocational training, university of applied science degree and university degree) are summarized to three categories. Missing and inconsistent data on education are corrected according to the imputation procedure described in Fitzenberger et al. (2006). The basic idea of this procedure is that individuals cannot lose their educational degrees.

${ }^{24}$ The estimated coefficient for the female dummy gives the mean actual wage gap.

${ }^{25}$ Hunt (2002) points out that the lower gender wage gap is due to a selection of better qualified women in employment, while the unskilled women are rather unemployed or out of labor force.
} 
individuals in the establishment, I can calculate this variable directly. For comparison, I have also used the self-reported information from the IAB Establishment Panel. There are only small deviations between both measures. In the subsequent empirical analysis I have used the calculated proportion of female employees. ${ }^{26}$

Row 1 in Tables A3 and A4 (in the appendix) presents the average proportion of females across establishments. An average man works in an establishment where women represent around one fourth of the workforce. Regarding this point the figures in western and eastern Germany are very similar. In contrast to this, women typically work in establishments where the proportion of females is around 50 percent of the establishment's workforce in western Germany and around 60 percent of the labor force of an establishment in eastern Germany. Thus women tend to work in predominately female establishments, with the opposite being true for men.

I use a detailed set of establishment variables to control for firm heterogeneity that may have been unobserved in previous studies. The set includes the size of establishments, the application of collective wage agreements (firm-specific and industry-wide), presence of a works council in the establishment, sales and wage bill per employee, state of the technology, the type of industry and the region where the establishment is located. I use additionally information on workplace attributes which might be related to gender specific preferences. I include a number of variables describing the extent of working hours in an establishment. Furthermore, I exploit information regarding an establishment's practices for reconciling family and working life as well as practices for health promotion. Arrangements to improve the work-life balance comprise, for instance, a firm kindergarten or other child care facilities, mentoring programs for female members of staff, equal opportunity commissioners and so on. Tables A3 and A4 in the appendix show that both practices for reconciling family and working life as well as practices for health promotion are more common in establishments in western Germany than in eastern Germany. In both regions male employees rather work in establishments with programs promoting health than women do, while the opposite is true for programs to improve the work-life balance. In addition, the establishments provide information on which worker characteristics are important for the workplaces. I use information as to whether employees have to be especially flexible and need to be able to work under physical and mental pressure.

\footnotetext{
${ }^{26}$ I also test the other variable and detect no qualitative differences and only quantitative differences between the estimation results.
} 


\section{Empirical results}

In the empirical analysis, I investigate the impact of the proportion of females within establishments on wages of male and female employees. In Section 3, I introduced three hypotheses through which I established a relationship between gender segregation across establishments and individual wages. In the empirical analysis, I attempt to test these hypotheses. The first is based on gender differences in preferences, suggesting that the proportion of females captures the impact of workplace characteristics favored by women. In this framework the impact of sex segregation on wages is negative for both male and female employees according to the theory of compensating wage differentials. In the second hypothesis, it is assumed that women are less well-qualified, thus involving lower wage rates. In such cases the proportion of women reflects the low qualification needs of the establishment and is connected with lower wage rates. The third hypothesis is based on discriminatory behavior against women by the employer. The impact of the proportion of females is negative on male wages and positive on female wages because the proportion of females is inversely related to the degree of discrimination.

The empirical strategy is as follows: I successively include individual and establishmentspecific variables describing a) the qualification and b) workplace characteristics in the wage regression of male and female employees. By observing the impact of the proportion of females on individual wages of male and female employees for each of the various specifications, I can test the previously discussed hypotheses concerning what lies behind the impact of the proportion of females within firms. That means I interpret the changes in the estimated coefficient of the interesting variable caused by the inclusion of information.

For readability, Table 4.1 only presents coefficient estimates and corresponding standard errors for the main indicator of interest, the proportion of females within establishments. The complete regression results of the all specifications are in Tables A5, A6, A7 and A8 in the appendix.

I start with wage regressions for male and female employees using only the proportion of females and a constant as explanatory variables. There appears to be a positive relationship between the wage rate and the variable of interest for male employees in western and eastern Germany. By contrast, it seems that women earn less in establishments with a high proportion of females. However, the estimated parameter is not significant for eastern German women. The explanatory power of that specification is not very large. I compare here, for instance, a man employed in senior positions in a typical female dominated 
establishment such as a supermarket with an unqualified worker in a construction firm.

Table 1: Coefficients for the establishment proportion of females in various specification of a log wage equation

\begin{tabular}{|c|c|c|c|c|c|}
\hline \multirow{2}{*}{\multicolumn{2}{|c|}{ Specification }} & \multicolumn{2}{|c|}{ Western Germany } & \multicolumn{2}{|c|}{ Eastern Germany } \\
\hline & & Males & Females & Males & Females \\
\hline (1) & proportion of females & $0.1071^{\star \star \star}$ & $-0.2316^{\star \star \star}$ & $\begin{array}{l}0.1717^{\star \star \star} \\
(0.0567)\end{array}$ & $\begin{array}{l}-0.0099 \\
\quad(0.0567)\end{array}$ \\
\hline (2) & $\begin{array}{l}(1)+\text { human capital + occupation } \\
+ \text { regions }\end{array}$ & $\begin{array}{r}-0.2082^{\star * \star} \\
(0.0241)\end{array}$ & $\begin{array}{l}-0.2669^{\star \star \star} \\
(0.0254)\end{array}$ & $\begin{array}{l}-0.0889^{*} \\
(0.0458)\end{array}$ & $\begin{array}{l}-0.0819 \\
(0.0556)\end{array}$ \\
\hline (3) & $(2)+$ establishment size + industry & $\begin{array}{r}-0.1687^{\star \star \star} \\
(0.0215)\end{array}$ & $\begin{array}{l}-0.2194^{\star \star \star} \\
(0.0277)\end{array}$ & $\begin{aligned}-0.1413^{* * *} & (0.0331)\end{aligned}$ & $\begin{aligned}-0.2452^{\star \star \star} & (0.0399)\end{aligned}$ \\
\hline (4) & (3) + institutional setting & $\begin{array}{r}-0.1645^{\star \star \star} \\
(0.0204)\end{array}$ & $\begin{aligned}-0.1770^{* \star *} & (0.0263)\end{aligned}$ & $\begin{aligned}-0.1293^{* * *} & (0.0325)\end{aligned}$ & $\begin{aligned}-0.1993^{\star * \star} & (0.0338)\end{aligned}$ \\
\hline (5) & (4) + achievement potential & $\begin{array}{r}-0.0870^{* * *} \\
(0.0195)\end{array}$ & $\begin{array}{l}-0.0520^{* *} \\
(0.0232)\end{array}$ & $\begin{aligned}-0.0684^{* *} & (0.0351)\end{aligned}$ & $\begin{aligned}-0.1202^{* * \star} & (0.0330)\end{aligned}$ \\
\hline (6) & (5) + workplace characteristics & $\begin{array}{l}-0.0793^{\star \star \star} \\
(0.0188)\end{array}$ & $\begin{array}{l}-0.0462^{* *} \\
(0.0225)\end{array}$ & $\begin{aligned}-0.0728^{\star *} & (0.0345)\end{aligned}$ & $\begin{aligned}-0.1203^{\star \star *} & (0.0321)\end{aligned}$ \\
\hline (7) & (6) + interaction terms & $\begin{array}{r}-0.0728^{\star \star \star} \\
(0.0179) \\
\end{array}$ & $\begin{array}{r}-0.0458^{\star \star} \\
(0.0224) \\
\end{array}$ & $\begin{array}{r}-0.0703^{* *} \\
(0.0329) \\
\end{array}$ & $\begin{array}{r}-0.1209^{* * *} \\
(0.0309) \\
\end{array}$ \\
\hline \multicolumn{2}{|c|}{ Number of observations } & 565,100 & 192,814 & 120,985 & 75,340 \\
\hline
\end{tabular}

Note: The dependent variable is the log of the real daily wage. The results are based on Tobit regressions. Standard errors are in parentheses and are adjusted for clustering at the establishment level. The complete estimation results are in Tables A5 - A8. Significance levels: *: 10 percent **:5 percent ***: 1 percent

Source: own calculation, LIAB cross-sectional model 2002.

In the next specification, I control for human capital endowment and occupations. The estimated coefficients for the proportion of females turn out to be negative for men both in western and eastern Germany. For women the estimated coefficients in this specification are more negative than in the first specification. So far, the results show that men and women respectively earn less in a female dominated firm than men and women respectively with the same observed human capital and occupation in an establishment with a lower proportion of women. These results contradict the second hypothesis that establishments with a high proportion of females rather employ unqualified workers. If this hypothesis were true the estimated coefficients for the proportion of females would have to be larger in the specification controlling for qualification than in the specification without such controls. ${ }^{27}$ In the third specification, I further include the establishment size (in terms of the number of employees) and the industry as explanatory variables in the wage regressions. The results show significant negative coefficients for the impact of the proportion of females on individual wages for both gender groups in western and eastern Germany. Furthermore, the estimated effect of the interesting variable is larger for female employees than for male

\footnotetext{
${ }^{27}$ Note, I only control for observed qualification. A sorting based on unobserved skills is also possible and is not accounted for in that estimation approach.
} 
employees. This pattern also appears in most international studies that control for the same firm-specific variables (see e.g. Bayard et al. 2003).

In comparison to the second specification, the relationship between the proportion of females and individual wages is weaker in western Germany if I control for the establishment size and type of industry. This change is due to the selection of women in smaller firms paying at average lower wage rates (see results in Tables A5 and A6 in the appendix). A different pattern can be found in eastern Germany. The estimated coefficients for the effect of the proportion of females are smaller (more negative) for both gender groups in the third specification than in the second. Unlike in western Germany, women in eastern Germany tend to work in larger establishments.

By controlling for the presence of a works council and the application of a collective bargaining agreement in the establishment, the estimated coefficient for the impact of the proportion of women becomes larger (less negative) for both gender groups in eastern as well as in western Germany in comparison to the last specification. This result suggests that female employees benefit more in terms of wages from the presence of a works council and the application of a wage agreement than male employees do.

In the fifth specification, I further include variables reflecting achievement potential. I additionally take into account the sales and the wage bill per employee as well as a dummy for a state of the technology. Again the estimated coefficients for the interesting variable dramatically increase (become less negative) in all four sub-samples compared to the last specification. This is particularly pronounced for women in western Germany. The impact of the proportion of females is now only significant at the 5 percent level. Furthermore in western Germany, the effect of that variable is now larger for male than for female employees, a finding which differs to most other studies. The opposite pattern appears in eastern Germany. Here, the estimated effect of the proportion of females on individual wages is still larger (more negative) for women while the coefficient is only significant at the 5 percent level for men.

In the sixth specification, I include a large set of variables reflecting workplace attributes which could describe a selection of male and female employees in firms. In detail these variables comprise the weekly working hours, a dummy for overtime and dummy for no compensations for overtime working in terms of leisure or payments. Furthermore I include information on whether the firms explicitly implement measures to promote health and arrangements to improve the work-life balance. I also control as to whether the employers demand a high degree of flexibility and a high degree of mental and physical fitness from 
their employees.

For western Germany, the results show a further weakening of the relationship between the proportion of females within establishments and the individual wages for male and female employees. However, the reduction of the partial correlation is marginal compared to my expectations. In eastern Germany, the estimated coefficients for the proportion of females even decrease in comparison to the last specification. Thus the coefficients are more negative than they would be without controlling for the defining workplace attributes. This result is puzzling as it contradicts the descriptive findings which show that the proportion of women is higher in firms with these workplace characteristics. An explanation could be that the effects of these variables are captured by other characteristics for which I have controlled in previous specifications. For instance, the data shows that firms with works councils and collective bargaining also offer arrangements to improve the work-life balance and less weekly working hours. In order to test this, I have changed the sequence of including firmspecific characteristics. The results are presented in Table A9 in the appendix. After controlling for individual characteristics, I start by taking into account the large set of workplace attributes. In the third specification, the estimated coefficient for the impact of the proportion of females becomes larger (less negative) for both gender groups in eastern as well as in western Germany in comparison to the last specification, controlling for individual characteristics. The weakening of the relationship between wages and the proportion of women within firms is now more pronounced than the observed change from specification five to six in Table 4.1. After controlling for workplace characteristics, I continue to include the other firm characteristics (see Table A9 in the appendix). In western Germany, the impact of the interesting variable changes only slightly until I take into account variables reflecting the achievement potential of the firm. Then the estimated coefficient for the proportion of females again increases dramatically (less negative) for male and female employees. In eastern Germany, controlling for establishment size and type of industry again leads to an decrease of the estimated coefficient for the interesting variable. As mentioned above, this is because women in eastern Germany tend to work in larger establishments.

This robustness check confirms the first hypothesis that the proportion of females reflects the attractiveness of the workplace for female employees for both western and eastern Germany. This is often captured by other firm characteristics such as work councils or collective bargaining agreements.

I also check whether the workplace characteristics have different effects for different types of employees by including interaction terms between individual characteristics (human 
capital and occupation). However, as specification seven shows, the impact of the proportion of females within establishments on individual wages does not change compared to the specification without the interaction term.

Regarding the second hypothesis my previous estimates show that the proportion of females within establishments does not reflect the demand for unqualified workers. I check the robustness of this result by running all specifications of the wage equations without controlling for productivity-related characteristics. I present the estimated coefficients for the proportion of females in Table A10 in the appendix. For male employees, I find that the estimated coefficient for the impact of the proportion of females is always positive in the wage equations without controlling for human capital and occupation. Thus the estimated coefficient for the interesting variable is smaller in the wage equation with controls for individual productivity. This result supports the conclusion that the second hypothesis does not hold. Otherwise, the effect would have to increase when controlling for productivity because these controls would absorb the negative effect of the lower productivity from the effect of proportion of females.

However, for female employees such a clear pattern does not appear. For women, the estimated coefficient for the impact of the proportion of females within establishments is larger (less negative) in specifications with controls for individual productivity than in the specifications without these controls. This supports the hypothesis that establishments with a high proportion of females demand less qualified and thus primarily female workers who are paid less.

The last specification shows that a negative relationship between the proportion of females within establishments and wages for male and female employees still exists. In eastern Germany the relationship is more negative for women than for men. This result is in accordance with most other empirical studies. In contrast, in western Germany the negative connection between both variables is stronger for male employees. I cannot directly test the third hypothesis since I cannot capture the monopsony power and discriminatory preferences in observable firm characteristics. However, in the last specification I control for productivity-related and firm-specific characteristics. Thus the remaining effect of the proportion of females on wages should be an indicator of employer discrimination. The residual effect is still negative and significant for male and female employees, but is reduced in magnitude. In eastern Germany the effect is larger for women than for men, while in western Germany the reverse holds true. So far, the estimation results do not support the discrimination hypothesis. In this hypothesis, the proportion of females within 
establishments reflects the degree of prejudice against women among employers: the higher the aversion against women is, the lower the proportion of females. Furthermore, more discriminatory employers pay women less than employers who are more favorably disposed towards women. Thus this hypothesis predicts a positive relationship between individual wages and the proportion of females. The estimation results do not show this. ${ }^{28}$ Perhaps there is an alternative explanation as to what drives the impact of the proportion of females on individual wages.

\section{Conclusions}

In this study I examine why the segregation of women across establishments affects the wages of male and female employees. To investigate this issue, I use matched employeremployee data from eastern and western Germany. The IAB Linked Employer-Employee panel (LIAB) combines data from the IAB Establishment Panel and the Employment Statistics Register. The data set is rich in both worker as well as establishment characteristics and includes particularly relevant information concerning the workforce composition of firms.

My empirical results confirm the results of previous international studies (e.g. Reilly and Wirjanto 1999a, Bayard et al. 2003, Amuedo-Dorantes and De la Rica 2006) which show a negative relationship between the proportion of females within establishments and individual wages of men and women. However, it is not always clear what is actually measured by the impact of the proportion of females on wage rates as potentially important information is omitted. For this reason I attempt to go one step further. Why should there be an effect of the sex segregation on individual earnings? I present three hypotheses. Firstly, assuming gender differences in preferences for specific firm and workplace characteristics, the proportion of women in an establishment reflects the attractiveness of a given workplace for women for which they are willing to accept lower wage rates in return. Secondly, I present a qualification hypothesis in relation to the so-called quality sorting hypothesis. According to this hypothesis, the proportion of females is a proxy for the skill requirements of the firm. This model framework predicts that women (men) will be over-represented in firms that demand comparatively less (more) skilled labor, so that the gender composition effect is negative on both male and female wages. As a third hypothesis, I suppose that

\footnotetext{
${ }^{28}$ However, I can speculate that controlling for more workplace attributes would lead to a further decrease in the estimated coefficients, at least for Western Germany. Maybe the estimated coefficients turn to a positive sign. However, this is a speculation.
} 
discriminatory behavior against women by the employer can be a reason for a connection between the proportion of females within firms and individual wages. I use for this a Becker/Arrow model of employer discrimination embedded in a monopsonisitic framework in order to allow for heterogeneous wages across firms. Firms are assumed to be heterogeneous in terms of discriminatory preferences. Since the degree of discrimination against females is negatively correlated with the proportion of females within establishments and with female wages, the model framework predicts a positive relationship between the proportion of females and the wage rate for women. Furthermore, the model framework would predict for male employees a negative relationship with the proportion of females.

The empirical analysis does not support the last hypothesis because both men and women continue to be paid less in female dominated firms after controlling for productivity-related individual and firm characteristics. Moreover, this remaining negative impact for women is larger in eastern than in western Germany. As one of the omitted firm characteristic in the wage regression is the market structure, one explanation for this difference between eastern and western Germany may be that firms in eastern German can particularly exploit women due to their monopsonistic power.

The second hypothesis is partly confirmed. It seems that the proportion of females partly reflects the low qualification of female employees, but low-qualified men are not selected in firms with a predominantly female workforce. As discussed before, these results only refer to the observed individual qualification. It is still possible that men and women with low unobserved labor productivity are selected by firms with a high proportion of females. In order to investigate this issue, a panel analysis is necessary. Macpherson and Hirsch (1995) investigate the quality sorting hypothesis for occupational segregation. Using a longitudinal analysis, they find that female dominated occupations reduce wages. They conclude that unobserved person-specific labor quality or preferences account for much of the negative relationship. However, a panel analysis is unable to ascertain whether the weakening of the relationship is due to preferences or labor quality. For this reason, this study chose a different methodological approach based on cross-section data. ${ }^{29}$

As the strongest finding, my empirical analysis shows that the impact of the proportion of females within establishments on wages mainly captures a selection of male and female employees in different types of firms. It seems that women tend to prefer firms that offer

\footnotetext{
${ }^{29}$ I also use longitudinal data for the years 2000 to 2005. The estimations results show no significant effect of the proportion of females on individual wages. The comparison of longitudinal results and cross-section estimates suggests, that unmeasured, time-invariant worker- and establishment specific effects are correlated with establishment proportion of females. However, I cannot disentangle whether this effect is due to preferences, individual productivity or the behaviour of the employer.
} 
better chances of reconciling family and work responsibilities and also accept lower wages in return. This outcome might reflect that a general lack of child care facilities in Germany creates a pressure on women to seek remedy for this lack of public infrastructure in the sphere of the work environment. As only some firms provide attractive workplaces, this constraints the number of employment opportunities for women and therefore creates a downward pressure on their wages. If this was true, such selection processes should be weaker in countries with a better public infrastructure for reconciling family and work responsibilities. This points to the need for an empirical cross-country comparison of the gender-specific workplace selection. Moreover, from a policy perspective, creating equal employment opportunities between men and women might be an important instrument for reducing the gender wage gap. For this purpose, policies should either aim at improving the public infrastructure and/or create incentives for men to take up an equal burden of child care responsibilities. 


\section{Appendix}

Table A 1: Summary statistics of individual characteristics for male and female employees, western Germany

\begin{tabular}{|c|c|c|c|c|}
\hline \multirow[b]{2}{*}{ Variables } & \multicolumn{2}{|c|}{ Males } & \multicolumn{2}{|c|}{ Females } \\
\hline & Mean & Std. dev. & Mean & Std. dev. \\
\hline Log wage & 4.6214 & 0.2683 & 4.4358 & 0.3440 \\
\hline Age & 40.5572 & 7.9364 & 39.4871 & 8.5406 \\
\hline Job tenure (in months) & 127.3092 & 96.8090 & 109.2366 & 91.0117 \\
\hline Foreigner & 0.1029 & 0.3038 & 0.0823 & 0.2748 \\
\hline Without vocational training degree & 0.1431 & 0.3502 & 0.1882 & 0.3909 \\
\hline With vocational training degree & 0.7048 & 0.4561 & 0.7101 & 0.4537 \\
\hline Graduate degree & 0.1520 & 0.3591 & 0.1016 & 0.3022 \\
\hline Simple blue-collar occupation & 0.2509 & 0.4335 & 0.1519 & 0.3589 \\
\hline Qualified blue-collar occupation & 0.1995 & 0.3996 & 0.0415 & 0.1995 \\
\hline Engineers & 0.1682 & 0.3740 & 0.0574 & 0.2325 \\
\hline Service occupation & 0.1282 & 0.3343 & 0.1173 & 0.3218 \\
\hline Clerical and administrative occupation & 0.1814 & 0.3854 & 0.4540 & 0.4979 \\
\hline Profession, manager and others & 0.0719 & 0.2583 & 0.1780 & 0.3825 \\
\hline Censored wage rates & 0.2091 & 0.4067 & 0.0814 & 0.2734 \\
\hline Number of employees & 565,100 & & 192,814 & \\
\hline
\end{tabular}

Source: own calculation, LIAB cross-sectional model 2002.

Table A 2: Summary statistics of individual characteristics for male and female employees, eastern Germany

\begin{tabular}{llllll}
\hline \hline & \multicolumn{2}{c}{ Males } & & \multicolumn{2}{c}{ Females } \\
\cline { 2 - 3 } Variables & Mean & Std. dev. & & Mean & Std. dev. \\
\hline Log wage & 4.2680 & 0.3239 & & 4.1916 & 0.3743 \\
Age & 41.5545 & 7.9294 & & 41.7276 & 7.8038 \\
Job tenure (in months) & 77.4810 & 43.7862 & & 79.6125 & 43.4014 \\
Foreigner & 0.0099 & 0.0989 & & 0.0065 & 0.0801 \\
Without vocational training degree & 0.0368 & 0.1882 & & 0.0355 & 0.1851 \\
With vocational training degree & 0.7929 & 0.4052 & & 0.8068 & 0.3948 \\
Graduate degree & 0.1703 & 0.3759 & & 0.1577 & 0.3644 \\
Simple blue-collar occupation & 0.2686 & 0.4432 & & 0.1455 & 0.3526 \\
Qualified blue-collar occupations & 0.2501 & 0.4331 & & 0.0444 & 0.2061 \\
Engineers & 0.1287 & 0.3349 & & 0.0708 & 0.2565 \\
Service occupation & 0.1632 & 0.3695 & & 0.1229 & 0.3283 \\
Clerical and administrative occupations & 0.0800 & 0.2712 & & 0.3361 & 0.4724 \\
Profession, manager and others & 0.1094 & 0.3122 & & 0.2802 & 0.4491 \\
Censored wage rate & 0.1054 & 0.3071 & & 0.0571 & 0.2320 \\
\hline Number of employees & 120,985 & & & 75,340 & \\
\hline \hline
\end{tabular}

Source: own calculation, LIAB cross-sectional model 2002. 
Table A 3: Summary statistics of establishment characteristics for male and female employees, western Germany

\begin{tabular}{|c|c|c|c|c|}
\hline \multirow[b]{2}{*}{ Variables } & \multicolumn{2}{|c|}{ Males } & \multicolumn{2}{|c|}{ Females } \\
\hline & Mean & Std. dev. & Mean & Std. dev. \\
\hline Establishment proportion of females & 0.2419 & 0.1935 & 0.4870 & 0.2411 \\
\hline Employment size $\left(1 / 10^{3}\right)$ & 3.4952 & 6.5812 & 2.4588 & 5.1064 \\
\hline Industry-wide wage agreement & 0.7784 & 0.4153 & 0.7727 & 0.4191 \\
\hline Firm-specific wage agreement & 0.1209 & 0.3260 & 0.0969 & 0.2958 \\
\hline No wage agreement & 0.1008 & 0.3010 & 0.1304 & 0.3367 \\
\hline Works council & 0.9158 & 0.2777 & 0.8888 & 0.3144 \\
\hline Sales per employee $\left(1 / 10^{5}\right)$ & 10.7694 & 63.6161 & 17.3609 & 79.1176 \\
\hline Wage bill per employee $\left(1 / 10^{4}\right)$ & 0.2975 & 0.0945 & 0.2656 & 0.1027 \\
\hline Very high or high state of the technology & 0.7624 & 0.4256 & 0.7622 & 0.4258 \\
\hline Average weekly working hours & 36.9283 & 2.1720 & 37.6515 & 1.7136 \\
\hline Overtime & 0.9525 & 0.2128 & 0.9264 & 0.2612 \\
\hline No overtime compensation & 0.0023 & 0.0478 & 0.0047 & 0.0687 \\
\hline Measures for improving work-child compatibility & 0.4625 & 0.4986 & 0.4749 & 0.4994 \\
\hline Workplace health promotion & 0.8725 & 0.3335 & 0.8418 & 0.3649 \\
\hline Workplace with physical or mental stress & 0.3860 & 0.4868 & 0.3964 & 0.4892 \\
\hline Workplace with high flexibility needs & 0.6463 & 0.4781 & 0.6315 & 0.4824 \\
\hline West Berlin & 0.0464 & 0.2104 & 0.0596 & 0.2368 \\
\hline Schleswig Holstein & 0.0474 & 0.2126 & 0.0593 & 0.2362 \\
\hline Hamburg & 0.0563 & 0.2305 & 0.0599 & 0.2374 \\
\hline Lower Saxony & 0.0959 & 0.2944 & 0.0863 & 0.2808 \\
\hline Bremen & 0.0288 & 0.1673 & 0.0349 & 0.1835 \\
\hline North Rhine-Westphalia & 0.2146 & 0.4105 & 0.2023 & 0.4017 \\
\hline Hesse & 0.1301 & 0.3364 & 0.1280 & 0.3341 \\
\hline Rhineland-Palatinate & 0.0448 & 0.2070 & 0.0539 & 0.2258 \\
\hline Baden-Wuerttemberg & 0.1322 & 0.3387 & 0.1399 & 0.3469 \\
\hline Bavaria & 0.1428 & 0.3499 & 0.1433 & 0.3504 \\
\hline Saarland & 0.0606 & 0.2386 & 0.0327 & 0.1778 \\
\hline Agriculture and forestry & 0.0024 & 0.0486 & 0.0016 & 0.0400 \\
\hline Electricity, gas and water supply, mining & 0.0278 & 0.1645 & 0.0130 & 0.1132 \\
\hline Manufacturing & 0.6241 & 0.4844 & 0.3825 & 0.4860 \\
\hline Construction & 0.0282 & 0.1656 & 0.0076 & 0.0868 \\
\hline Wholesale and retail trade & 0.0429 & 0.2026 & 0.0710 & 0.2568 \\
\hline Transport and communication & 0.0575 & 0.2328 & 0.0274 & 0.1631 \\
\hline Financial intermediation & 0.0646 & 0.2459 & 0.1411 & 0.3481 \\
\hline Real estate, renting and business activities & 0.0601 & 0.2377 & 0.0678 & 0.2514 \\
\hline Other service activities & 0.0923 & 0.2895 & 0.2881 & 0.4529 \\
\hline Number of establishments & 5,533 & & 5,133 & \\
\hline Number of employees & 565,100 & & 192,814 & \\
\hline
\end{tabular}

Source: own calculation, LIAB cross-sectional model 2002. 
Table A 4: Summary statistics of establishment characteristics for male and female employees, eastern Germany

\begin{tabular}{|c|c|c|c|c|}
\hline \multirow[b]{2}{*}{ Variables } & \multicolumn{2}{|c|}{ Males } & \multicolumn{2}{|c|}{ Females } \\
\hline & Mean & Std. dev. & Mean & Std. dev. \\
\hline Establishment proportion of females & 0.2791 & 0.2186 & 0.5915 & 0.2504 \\
\hline Employment size $\left(1 / 10^{3}\right)$ & 0.8036 & 1.3813 & 0.8253 & 1.1746 \\
\hline Industry-wide wage agreement & 0.5417 & 0.4983 & 0.5893 & 0.4920 \\
\hline Firm-specific wage agreement & 0.1970 & 0.3977 & 0.1607 & 0.3673 \\
\hline No wage agreement & 0.2613 & 0.4393 & 0.2499 & 0.4330 \\
\hline Works council & 0.7740 & 0.4183 & 0.7984 & 0.4012 \\
\hline Sales per employee $\left(1 / 10^{5}\right)$ & 2.3112 & 8.7614 & 3.3196 & 13.6779 \\
\hline Wage bill per employee $\left(1 / 10^{4}\right)$ & 0.2189 & 0.0887 & 0.2065 & 0.0809 \\
\hline Very high or high state of the technology & 0.7553 & 0.4299 & 0.7254 & 0.4463 \\
\hline Average weekly working hours & 39.2733 & 1.4678 & 39.4793 & 1.2643 \\
\hline Overtime & 0.8606 & 0.3463 & 0.7746 & 0.4178 \\
\hline No overtime compensation & 0.0056 & 0.0746 & 0.0040 & 0.0631 \\
\hline Measures for improving work-child compatibility & 0.2442 & 0.4296 & 0.3002 & 0.4583 \\
\hline Workplace health promotion & 0.8300 & 0.3756 & 0.8200 & 0.3842 \\
\hline Workplace with physical or mental stress & 0.4621 & 0.4986 & 0.5028 & 0.5000 \\
\hline Workplace with high flexibility needs & 0.6207 & 0.4852 & 0.6042 & 0.4890 \\
\hline Berlin-East & 0.0547 & 0.2274 & 0.0734 & 0.2608 \\
\hline Mecklenburg-Western Pomerania & 0.1530 & 0.3600 & 0.1614 & 0.3679 \\
\hline Brandenburg & 0.1240 & 0.3296 & 0.1069 & 0.3089 \\
\hline Saxony-Anhalt & 0.2818 & 0.4499 & 0.2428 & 0.4288 \\
\hline Thuringia & 0.1889 & 0.3914 & 0.2184 & 0.4132 \\
\hline Saxony & 0.1976 & 0.3982 & 0.1971 & 0.3978 \\
\hline Agriculture and forestry & 0.0212 & 0.1440 & 0.0159 & 0.1250 \\
\hline Electricity, gas and water supply, mining & 0.0668 & 0.2497 & 0.0402 & 0.1963 \\
\hline Manufacturing & 0.4809 & 0.4996 & 0.2819 & 0.4499 \\
\hline Construction & 0.0923 & 0.2894 & 0.0159 & 0.1249 \\
\hline Wholesale and retail trade & 0.0374 & 0.1897 & 0.0383 & 0.1920 \\
\hline Transport and communication & 0.0770 & 0.2666 & 0.0285 & 0.1664 \\
\hline Financial intermediation & 0.0152 & 0.1222 & 0.0580 & 0.2338 \\
\hline Real estate, renting and business activities & 0.0524 & 0.2228 & 0.0616 & 0.2404 \\
\hline Other service activities & 0.1569 & 0.3637 & 0.4598 & 0.4984 \\
\hline Number of establishments & 3.035 & & 2.746 & \\
\hline Number of employees & 120,985 & & 75,340 & \\
\hline
\end{tabular}

Source: own calculation, LIAB cross-sectional model 2002. 
Table A 5: Estimates of Tobit wage regressions for male employees, western Germany

\begin{tabular}{|c|c|c|c|c|c|c|}
\hline \multirow[b]{2}{*}{ Variables } & \multicolumn{2}{|c|}{ Specification (1) } & \multicolumn{2}{|c|}{ Specification (2) } & \multicolumn{2}{|c|}{ Specification (3) } \\
\hline & Coeff. & Std. Err & Coeff. & Std. Err. & Coeff. & Std. Err. \\
\hline Female proportion & $0.1071^{\star \star \star}$ & 0.0368 & $-0.2082^{\star \star \star}$ & 0.0241 & $-0.1687^{* \star *}$ & 0.0215 \\
\hline Age & & & $0.0320^{\star \star *}$ & 0.0020 & $0.0343^{\star \star \star}$ & 0.0017 \\
\hline Age squared $\left(1 / 10^{2}\right)$ & & & $-0.0336^{\star \star \star}$ & 0.0021 & $-0.0353^{\star \star \star}$ & 0.0019 \\
\hline Job tenure (in month) & & & $0.0014^{\star * *}$ & 0.0001 & $0.0011^{\star \star *}$ & 0.0001 \\
\hline Job tenure squared $\left(1 / 10^{2}\right)$ & & & $-0.0003^{\star \star \star}$ & 0.0000 & $-0.0002^{\star \star \star}$ & 0.0000 \\
\hline Foreigner & & & -0.0053 & 0.0070 & $-0.0182^{\star \star \star}$ & 0.0047 \\
\hline Without vocational training & & & $-0.1099^{* \star *}$ & 0.0066 & $-0.1003^{\star \star *}$ & 0.0059 \\
\hline Graduate degree & & & $0.2855^{\star \star \star}$ & 0.0084 & $0.2632^{\star \star \star}$ & 0.0079 \\
\hline Simple blue-collar occupation & & & $0.0318^{\star \star}$ & 0.0123 & -0.0135 & 0.0114 \\
\hline Qualified blue-collar occupation & & & $0.0742^{\star \star \star}$ & 0.0121 & $0.0423^{\star \star \star}$ & 0.0105 \\
\hline Engineers & & & $0.3283^{* * *}$ & 0.0153 & $0.2924^{\star \star \star}$ & 0.0143 \\
\hline Clerical and administrative occupation & & & $0.3283^{\star * *}$ & 0.0157 & $0.2688^{\star \star \star}$ & 0.0136 \\
\hline Profession, manager and others & & & $0.3224^{\star * *}$ & 0.0153 & $0.3442^{\star \star \star}$ & 0.0128 \\
\hline Employment size $\left(1 / 10^{3}\right)$ & & & & & $0.0219^{\star \star \star}$ & 0.0023 \\
\hline Employment size squared $\left(1 / 10^{6}\right)$ & & & & & $-0.0005^{\star \star \star}$ & 0.0001 \\
\hline
\end{tabular}

Industry-wide wage agreement

Firm-specific wage agreement

Works council

Sales per employee $\left(1 / 10^{5}\right)$

Wage bill per employee $\left(1 / 10^{4}\right)$

Very high or high state of the technology

Average weekly working hours

Overtime

No overtime compensation

Improving work-child compatibility

Workplace health promotion

Workplace with physical or mental stress

Workplace with high flexibility needs

\begin{tabular}{lccc}
\hline Region / Industry controls / Interaction terms & no / no /no & yes /no /no & yes / yes /no \\
Log pseudolikelihood & $-243,255.22$ & $-55,910.22$ & $-24,232.26$ \\
\hline Observations & 565,100 & 565,100 & 565,100 \\
\hline
\end{tabular}

Note: The dependent variable is the log of the real daily wage. The results are based on Tobit regressions. Clustered standard errors at the establishment level. The estimated coefficients for the regional, industry controls and interaction terms are available upon request from the author.

Significance levels: *: 10 percent **:5 percent $* * *: 1$ percent

Source: LIAB cross-sectional model 2002. 
Table A 5, continued: Estimates of Tobit wage regressions for male employees, western Germany

\begin{tabular}{|c|c|c|c|c|c|c|}
\hline \multirow[b]{2}{*}{ Variables } & \multicolumn{2}{|c|}{ Specification (4) } & \multicolumn{2}{|c|}{ Specification (5) } & \multicolumn{2}{|c|}{ Specification (6) } \\
\hline & Coeff. & Std. Err. & Coeff. & Std. Err. & Coeff. & Std. Err. \\
\hline Female proportion & $-0.1645^{\star \star \star}$ & 0.0204 & $-0.0870 * * *$ & 0.0195 & $-0.0793^{\star \star *}$ & 0.0188 \\
\hline Age & $0.0347^{\star \star \star}$ & 0.0017 & 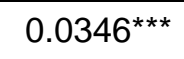 & 0.0016 & $0.0348^{\star \star \star}$ & 0.0016 \\
\hline Age squared $\left(1 / 10^{2}\right)$ & $-0.0359 * * *$ & 0.0019 & $-0.0358^{\star * *}$ & 0.0018 & $-0.0360^{* \star *}$ & 0.0017 \\
\hline Job tenure (in month) & $0.0010^{\star \star *}$ & 0.0001 & $0.0010^{\star \star \star}$ & 0.0001 & $0.0010^{\star \star \star}$ & 0.0001 \\
\hline Job tenure squared $\left(1 / 10^{2}\right)$ & $-0.0002^{\star \star *}$ & 0.0000 & $-0.0002^{\star \star \star}$ & 0.0000 & $-0.0002^{\star * *}$ & 0.0000 \\
\hline Foreigner & $-0.0168^{\star \star *}$ & 0.0046 & $-0.0188^{\star \star *}$ & 0.0043 & $-0.0184^{\star \star *}$ & 0.0042 \\
\hline Without vocational training & $-0.0981^{\star \star *}$ & 0.0056 & $-0.0921^{\star \star \star}$ & 0.0052 & $-0.0935^{\star \star \star}$ & 0.0050 \\
\hline Graduate degree & $0.2572^{\star \star \star}$ & 0.0077 & $0.2380^{\star \star \star}$ & 0.0070 & $0.2367^{\star \star \star}$ & 0.0067 \\
\hline Simple blue-collar occupation & -0.0151 & 0.0113 & -0.0140 & 0.0096 & $-0.0170^{*}$ & 0.0092 \\
\hline Qualified blue-collar occupation & $0.0470^{\star \star *}$ & 0.0104 & $0.0437^{\star * \star}$ & 0.0092 & $0.0375^{\star \star *}$ & 0.0087 \\
\hline Engineers & $0.2924^{\star \star *}$ & 0.0139 & $0.2734^{\star \star \star}$ & 0.0123 & $0.2683^{\star \star \star}$ & 0.0116 \\
\hline Clerical and administrative occupation & $0.2691^{\star \star \star}$ & 0.0134 & 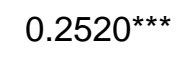 & 0.0114 & $0.2501^{\star \star \star}$ & 0.0108 \\
\hline Profession, manager and others & $0.3424^{\star \star \star}$ & 0.0125 & $0.3315^{\star \star \star}$ & 0.0116 & $0.3256^{\star * *}$ & 0.0111 \\
\hline Employment size $\left(1 / 10^{3}\right)$ & $0.0188^{\star * \star}$ & 0.0022 & $0.0140 * \star \star$ & 0.0024 & $0.0084^{\star \star \star}$ & 0.0021 \\
\hline Employment size squared $\left(1 / 10^{6}\right)$ & $-0.0004^{\star \star \star}$ & 0.0001 & $-0.0004^{\star \star \star}$ & 0.0001 & $-0.0002^{* * *}$ & 0.0001 \\
\hline Industry-wide wage agreement & $0.0404^{\star \star \star}$ & 0.0107 & $0.0420 * * \star$ & 0.0095 & $0.0321^{* * *}$ & 0.0092 \\
\hline Firm-specific wage agreement & $0.0470^{\star * \star}$ & 0.0146 & $0.0553^{\star \star \star}$ & 0.0137 & $0.0396^{\star * *}$ & 0.0123 \\
\hline Works council & $0.1210^{\star \star \star}$ & 0.0109 & $0.0878^{\star \star *}$ & 0.0104 & $0.0679 * \star *$ & 0.0103 \\
\hline Sales per employee $\left(1 / 10^{5}\right)$ & & & $-0.0002^{\star \star}$ & 0.0001 & $-0.0001^{*}$ & 0.0001 \\
\hline Wage bill per employee $\left(1 / 10^{4}\right)$ & & & $0.7247^{\star \star \star}$ & 0.0546 & $0.6975^{\star \star \star}$ & 0.0518 \\
\hline Very high or high state of the technology & & & $0.0343^{\star \star \star}$ & 0.0074 & $0.0362^{\star \star \star}$ & 0.0064 \\
\hline Average weekly working hours & & & & & $-0.0114^{\star \star *}$ & 0.0017 \\
\hline Overtime & & & & & $0.0434^{\star * *}$ & 0.0099 \\
\hline No overtime compensation & & & & & 0.0228 & 0.0228 \\
\hline Improving work-child compatibility & & & & & $0.0232^{\star \star \star}$ & 0.0071 \\
\hline Workplace health promotion & & & & & 0.0075 & 0.0075 \\
\hline Workplace with physical or mental stress & & & & & $0.0156^{\star *}$ & 0.0072 \\
\hline Workplace with high flexibility needs & & & & & 0.0053 & 0.0068 \\
\hline Region / Industry controls / Interaction terms & yes / ye & es /no & yes / ye & es /no & yes / ye & es/no \\
\hline Log pseudolikelihood & $-16,43$ & 33.64 & & & 4,492 & \\
\hline Observations & 565,1 & 100 & 565,1 & 100 & 565,1 & 100 \\
\hline
\end{tabular}

Note: The dependent variable is the log of the real daily wage. The results are based on Tobit regressions. Clustered standard errors at the establishment level. The estimated coefficients for the regional, industry controls and interaction terms are available upon request from the author.

Significance levels: *: 10 percent $* *: 5$ percent $* * *: 1$ percent

Source: LIAB cross-sectional model 2002. 
Table A 5, continued: Estimates of Tobit wage regressions for males employees, western Germany

\begin{tabular}{|c|c|c|c|c|c|c|}
\hline \multirow[b]{2}{*}{ Variables } & \multicolumn{2}{|c|}{ Specification (7) } & \multicolumn{2}{|c|}{ Specification (8) } & \multicolumn{2}{|c|}{ Specification (9) } \\
\hline & Coeff. & Std. Err. & Coeff. & Std. Err. & Coeff. & Std. Err. \\
\hline Female proportion & $-0.0728^{* \star *}$ & 0.0179 & $-0.1553^{\star \star *}$ & 0.0169 & $-0.1549 * \star \star$ & 0.0199 \\
\hline Age & $0.0347^{\star * \star}$ & 0.0015 & $0.0341^{\star * *}$ & 0.0017 & $0.0348^{\star \star \star}$ & 0.0016 \\
\hline Age squared $\left(1 / 10^{2}\right)$ & $-0.0359 * * *$ & 0.0017 & $-0.0355^{\star \star *}$ & 0.0018 & $-0.0359 * * *$ & 0.0018 \\
\hline Job tenure (in month) & $0.0010^{\star * *}$ & 0.0001 & $0.0012^{\star \star \star}$ & 0.0001 & $0.0011^{\star \star *}$ & 0.0001 \\
\hline Job tenure squared $\left(1 / 10^{2}\right)$ & $-0.0002^{\star \star \star}$ & 0.0000 & $-0.0002^{\star \star *}$ & 0.0000 & $-0.0002^{\star \star \star}$ & 0.0000 \\
\hline Foreigner & $-0.0185^{\star \star \star}$ & 0.0039 & 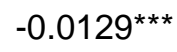 & 0.0046 & $-0.0171^{* \star *}$ & 0.0045 \\
\hline Without vocational training & 0.0317 & 0.0855 & $-0.1081^{\star \star \star}$ & 0.0059 & $-0.1014^{\star \star \star}$ & 0.0056 \\
\hline Graduate degree & 0.0264 & 0.1163 & $0.2672^{\star \star \star}$ & 0.0074 & $0.2588^{\star \star \star}$ & 0.0073 \\
\hline Simple blue-collar occupation & 0.1292 & 0.1769 & 0.0067 & 0.0104 & $-0.0191^{\star}$ & 0.0107 \\
\hline Qualified blue-collar occupation & 0.2440 & 0.1561 & $0.0513^{\star \star *}$ & 0.0096 & $0.0338^{\star \star \star}$ & 0.0097 \\
\hline Engineers & $0.9130^{\star * *}$ & 0.1799 & $0.3006^{\star \star *}$ & 0.0125 & $0.2828^{\star \star *}$ & 0.0132 \\
\hline Clerical and administrative occupation & $0.5887^{\star \star *}$ & 0.1797 & $0.3132^{* * *}$ & 0.0138 & $0.2649 * \star \star$ & 0.0125 \\
\hline Profession, manager and others & $1.0588^{\star \star *}$ & 0.2428 & $0.3082^{\star * *}$ & 0.0127 & 0.3350 *** & 0.0120 \\
\hline Employment size $\left(1 / 10^{3}\right)$ & $0.0079^{* * *}$ & 0.0021 & & & $0.0126^{\star * *}$ & 0.0023 \\
\hline Employment size squared $\left(1 / 10^{6}\right)$ & $-0.0002^{\star \star \star}$ & 0.0001 & & & $-0.0002^{\star \star \star}$ & 0.0001 \\
\hline Industry-wide wage agreement & $0.0306^{* * *}$ & 0.0089 & & & & \\
\hline Firm-specific wage agreement & $0.0379^{\star * *}$ & 0.0118 & & & & \\
\hline Works council & 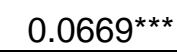 & 0.0101 & & & & \\
\hline Sales per employee $\left(1 / 10^{5}\right)$ & $-0.0001^{*}$ & 0.0001 & & & & \\
\hline Wage bill per employee $\left(1 / 10^{4}\right)$ & $0.6983^{\star \star *}$ & 0.0511 & & & & \\
\hline Very high or high state of the technology & $0.0355^{\star \star *}$ & 0.0062 & & & & \\
\hline Average weekly working hours & -0.0058 & 0.0037 & $-0.0226^{\star \star \star}$ & 0.0017 & $-0.0165^{\star \star \star}$ & 0.0023 \\
\hline Overtime & $0.0645^{\star \star \star}$ & 0.0377 & $0.0680 * \star *$ & 0.0121 & $0.0528^{\star \star *}$ & 0.0112 \\
\hline No overtime compensation & 0.0193 & 0.0233 & -0.0364 & 0.0324 & -0.0133 & 0.0279 \\
\hline Improving work-child compatibility & $0.0557^{\star \star \star}$ & 0.0153 & $0.0676^{\star \star \star}$ & 0.0090 & $0.0361^{\star \star \star}$ & 0.0080 \\
\hline Workplace health promotion & -0.0145 & 0.0235 & $0.0394^{\star \star *}$ & 0.0105 & $0.0252^{\star \star \star}$ & 0.0094 \\
\hline Workplace with physical or mental stress & $0.0380^{\star * *}$ & 0.0135 & 0.0080 & 0.0091 & 0.0124 & 0.0083 \\
\hline Workplace with high flexibility needs & 0.0023 & 0.0144 & $0.0164^{*}$ & 0.0086 & 0.0080 & 0.0076 \\
\hline Region / Industry controls / Interaction terms & yes / ye & es / yes & yes / y & es /no & yes / ye & es /no \\
\hline Log pseudolikelihood & 7,40 & & $-31,46$ & 34.76 & $-16,29$ & 99.04 \\
\hline Observations & 565 , & 100 & 565 , & 100 & 565, & 100 \\
\hline
\end{tabular}

Note: The dependent variable is the log of the real daily wage. The results are based on Tobit regressions. Clustered standard errors at the establishment level. The estimated coefficients for the regional, industry controls and interaction terms are available upon request from the author.

Significance levels: *: 10 percent $* *: 5$ percent $* * *: 1$ percent

Source: LIAB cross-sectional model 2002. 
Table A 5, continued: Estimates of Tobit wage regressions for males employees, western Germany

\begin{tabular}{|c|c|c|c|c|c|c|}
\hline \multirow[b]{2}{*}{ Variables } & \multicolumn{2}{|c|}{ Specification (10) } & \multicolumn{2}{|c|}{ Specification (11) } & \multicolumn{2}{|c|}{ Specification (12) } \\
\hline & Coeff. & Std. Err. & Coeff. & Std. Err. & Coeff. & Std. Err. \\
\hline Female proportion & $-0.1555^{\star \star \star}$ & 0.0195 & $0.0717^{\star *}$ & 0.0301 & $0.0671^{\star *}$ & 0.0302 \\
\hline Age & $0.0350^{\star * \star}$ & 0.0016 & & & & \\
\hline Age squared $\left(1 / 10^{2}\right)$ & $-0.0362^{\star \star \star}$ & 0.0018 & & & & \\
\hline Job tenure (in month) & $0.0010^{* * *}$ & 0.0001 & & & & \\
\hline Job tenure squared $\left(1 / 10^{2}\right)$ & $-0.0002^{\star \star \star}$ & 0.0000 & & & & \\
\hline Foreigner & $-0.0165^{\star \star \star}$ & 0.0044 & & & & \\
\hline Without vocational training & $-0.0993^{* \star *}$ & 0.0053 & & & & \\
\hline Graduate degree & $0.2549^{\star \star *}$ & 0.0073 & & & & \\
\hline Simple blue-collar occupation & $-0.0190^{\star \star}$ & 0.0106 & & & & \\
\hline Qualified blue-collar occupation & $0.0394^{\star * *}$ & 0.0097 & & & & \\
\hline Engineers & $0.2850 * * *$ & 0.0129 & & & & \\
\hline Clerical and administrative occupation & $0.2658^{\star \star *}$ & 0.0125 & & & & \\
\hline Profession, manager and others & $0.3351^{\star * *}$ & 0.0118 & & & & \\
\hline Employment size $\left(1 / 10^{3}\right)$ & $0.0123^{* * *}$ & 0.0022 & $0.0265^{\star * *}$ & 0.0029 & $0.0236^{\star * \star}$ & 0.0026 \\
\hline Employment size squared $\left(1 / 10^{6}\right)$ & $-0.0002^{\star \star \star}$ & 0.0001 & $-0.0005^{\star \star \star}$ & 0.0001 & $-0.0005^{\star \star \star}$ & 0.0001 \\
\hline Industry-wide wage agreement & $0.0287^{* * *}$ & 0.0102 & & & 0.0167 & 0.0194 \\
\hline Firm-specific wage agreement & $0.0286^{\star \star}$ & 0.0131 & & & -0.0106 & 0.0238 \\
\hline Works council & $0.0973^{\star \star \star}$ & 0.0110 & & & $0.1857^{\star \star \star}$ & 0.0160 \\
\hline \multicolumn{7}{|l|}{ Sales per employee $\left(1 / 10^{5}\right)$} \\
\hline \multicolumn{7}{|l|}{ Wage bill per employee $\left(1 / 10^{4}\right)$} \\
\hline \multicolumn{7}{|l|}{ Very high or high state of the technology } \\
\hline Average weekly working hours & $-0.0126^{\star \star \star}$ & 0.0021 & & & & \\
\hline Overtime & $0.0437^{\star \star \star}$ & 0.0110 & & & & \\
\hline No overtime compensation & 0.0136 & 0.0267 & & & & \\
\hline Improving work-child compatibility & $0.0294^{\star \star \star}$ & 0.0079 & & & & \\
\hline Workplace health promotion & 0.0083 & 0.0088 & & & & \\
\hline Workplace with physical or mental stress & $0.0145^{*}$ & 0.0080 & & & & \\
\hline Workplace with high flexibility needs & 0.0088 & 0.0075 & & & & \\
\hline Region / Industry controls / Interaction terms & \multicolumn{2}{|c|}{ yes / yes /no } & \multicolumn{2}{|c|}{ yes / yes / no } & \multicolumn{2}{|c|}{ yes / yes / no } \\
\hline Log pseudolikelihood & \multicolumn{2}{|c|}{$-11,981.09$} & \multicolumn{2}{|c|}{$-206,517.71$} & \multicolumn{2}{|c|}{$-198,969.22$} \\
\hline Observations & \multicolumn{2}{|c|}{565,100} & \multicolumn{2}{|c|}{565,100} & \multicolumn{2}{|c|}{565,100} \\
\hline
\end{tabular}

Note: The dependent variable is the log of the real daily wage. The results are based on Tobit regressions. Clustered standard errors at the establishment level. The estimated coefficients for the regional, industry controls and interaction terms are available upon request from the author.

Significance levels: *: 10 percent $* *: 5$ percent $* * *: 1$ percent

Source: LIAB cross-sectional model 2002. 
Table A 5, continued: Estimates of Tobit wage regressions for males employees, western Germany

\begin{tabular}{|c|c|c|}
\hline & Specification (13) & Specification (14) \\
\hline Variables & Coeff. Std. Err. & Coeff. Std. Err \\
\hline Female proportion & $0.1829^{\star \star \star} 0.0241$ & $0.1767^{\star \star \star} 0.0236$ \\
\hline \multicolumn{3}{|l|}{ Age } \\
\hline \multicolumn{3}{|l|}{ Age squared $\left(1 / 10^{2}\right)$} \\
\hline \multicolumn{3}{|l|}{ Job tenure (in month) } \\
\hline \multicolumn{3}{|l|}{ Job tenure squared $\left(1 / 10^{2}\right)$} \\
\hline \multicolumn{3}{|l|}{ Foreigner } \\
\hline \multicolumn{3}{|l|}{ Without vocational training } \\
\hline \multicolumn{3}{|l|}{ Graduate degree } \\
\hline \multicolumn{3}{|l|}{ Simple blue-collar occupation } \\
\hline \multicolumn{3}{|l|}{ Qualified blue-collar occupation } \\
\hline \multicolumn{3}{|l|}{ Engineers } \\
\hline \multicolumn{3}{|l|}{ Clerical and administrative occupation } \\
\hline \multicolumn{3}{|l|}{ Profession, manager and others } \\
\hline Employment size $\left(1 / 10^{3}\right)$ & $0.0147^{* \star \star} 0.0030$ & $0.0088^{\star \star \star} 0.0029$ \\
\hline Employment size squared $\left(1 / 10^{6}\right)$ & $-0.0004^{\star \star \star} 0.0001$ & $0.0002^{\star \star \star} 0.0001$ \\
\hline Industry-wide wage agreement & $0.0235^{*} \quad 0.0142$ & $0.0094 \quad 0.0140$ \\
\hline Firm-specific wage agreement & $0.0103 \quad 0.0176$ & $-0.0119 \quad 0.0172$ \\
\hline Works council & $0.1227^{\star \star \star} 0.0139$ & $0.1013^{\star \star \star} 0.0136$ \\
\hline Sales per employee $\left(1 / 10^{5}\right)$ & $-0.0003^{*} 0.0002$ & $0.0002^{*} 0.0001$ \\
\hline Wage bill per employee $\left(1 / 10^{4}\right)$ & $1.2600^{\star \star \star} 0.0819$ & $1.2143^{\star \star \star} 0.0766$ \\
\hline Very high or high state of the technology & $0.0465^{\star \star \star} 0.0083$ & $0.0476^{\star \star \star} 0.0079$ \\
\hline Average weekly working hours & & $0.0128^{\star \star \star} 0.0027$ \\
\hline Overtime & & $0.0590^{\star \star \star} 0.0136$ \\
\hline No overtime compensation & & $0.0727^{\star \star} 0.0319$ \\
\hline Improving work-child compatibility & & $0.0346^{\star \star \star} 0.0088$ \\
\hline Workplace health promotion & & $0.0019 \quad 0.0091$ \\
\hline Workplace with physical or mental stress & & $-0.0051 \quad 0.0086$ \\
\hline Workplace with high flexibility needs & & $0.0310^{\star \star \star} 0.0080$ \\
\hline Region / Industry controls / Interaction terms & yes / yes / no & yes / yes / no \\
\hline Log pseudolikelihood & $-169,955.29$ & $-166,251.24$ \\
\hline Observations & 565,100 & 565,100 \\
\hline
\end{tabular}

Note: The dependent variable is the log of the real daily wage. The results are based on Tobit regressions. Clustered standard errors at the establishment level. The estimated coefficients for the regional, industry controls and interaction terms are available upon request from the author.

Significance levels: *: 10 percent $* *: 5$ percent $* * *: 1$ percent

Source: LIAB cross-sectional model 2002. 
Table A 6: Estimates of Tobit wage regressions for female employees, western Germany

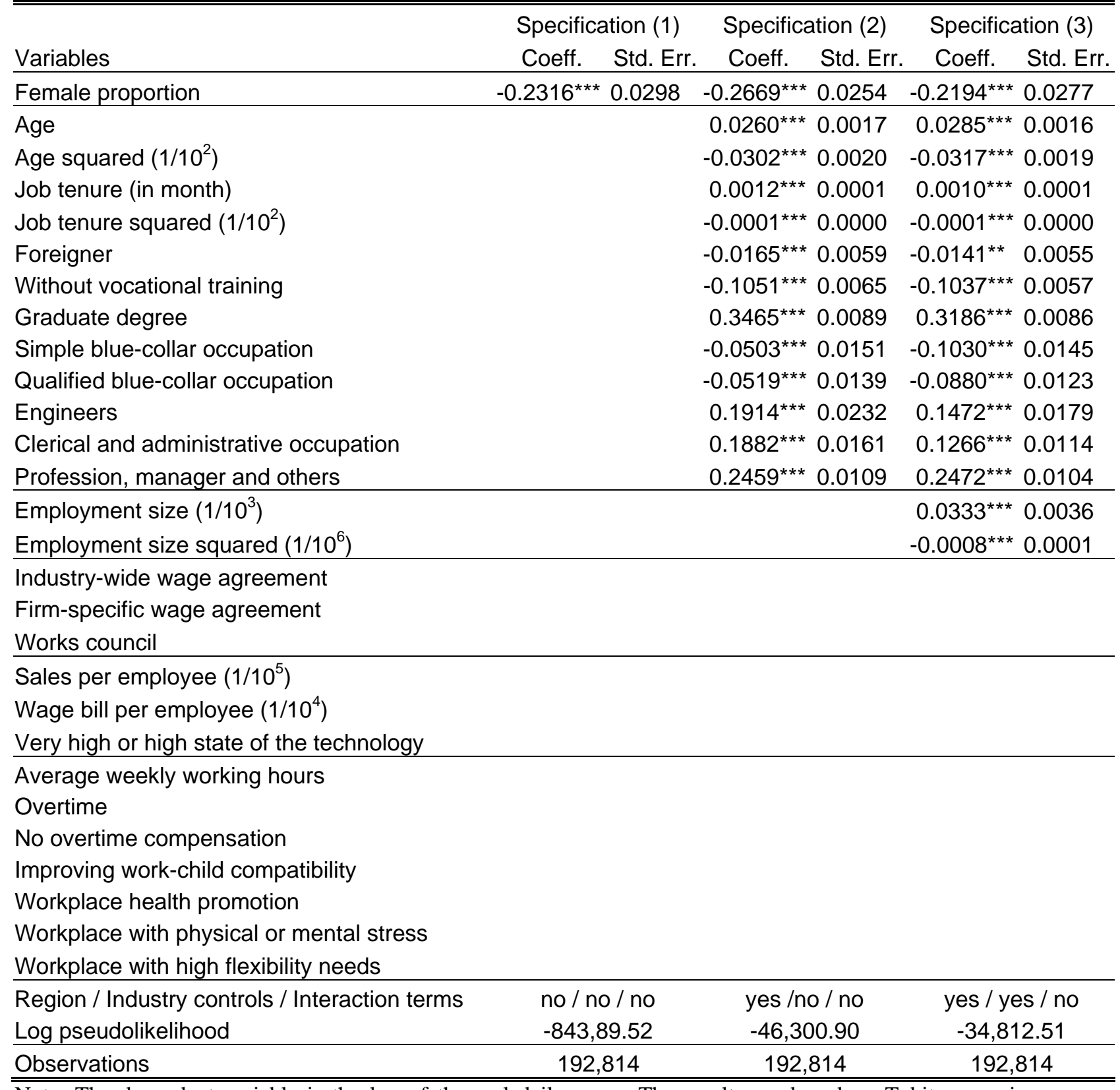

Note: The dependent variable is the log of the real daily wage. The results are based on Tobit regressions. Clustered standard errors at the establishment level. The estimated coefficients for the regional, industry controls and interaction terms are available upon request from the author.

Significance levels: *: 10 percent **:5 percent ***: 1 percent

Source: LIAB cross-sectional model 2002. 
Table A 6, continued: Estimates of Tobit wage regressions for female employees, western Germany

\begin{tabular}{|c|c|c|c|c|c|c|}
\hline \multirow[b]{2}{*}{ Variables } & \multicolumn{2}{|c|}{ Specification (4) } & \multicolumn{2}{|c|}{ Specification (5) } & \multicolumn{2}{|c|}{ Specification (6) } \\
\hline & Coeff. & Std. Err. & Coeff. & Std. Err. & Coeff. & Std. Err. \\
\hline Female proportion & $-0.1770^{\star \star \star}$ & 0.0263 & $-0.0520^{\star *}$ & 0.0232 & $-0.0462^{\star \star}$ & 0.0225 \\
\hline Age & $0.0293^{\star \star *}$ & 0.0016 & $0.0283^{\star \star *}$ & 0.0015 & $0.0284^{\star \star *}$ & 0.0015 \\
\hline Age squared $\left(1 / 10^{2}\right)$ & $-0.0326^{\star \star \star}$ & 0.0018 & $-0.0314^{\star \star *}$ & 0.0017 & $-0.0314^{\star \star *}$ & 0.0017 \\
\hline Job tenure (in month) & $0.0008^{\star \star \star}$ & 0.0001 & $0.0009 * \star \star$ & 0.0001 & 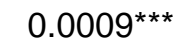 & 0.0001 \\
\hline Job tenure squared $\left(1 / 10^{2}\right)$ & $-0.0001^{\star \star \star}$ & 0.0000 & $-0.0001^{\star \star \star}$ & 0.0000 & $-0.0001^{\star \star \star}$ & 0.0000 \\
\hline Foreigner & $-0.0147^{\star \star \star}$ & 0.0052 & $-0.0182^{\star \star \star}$ & 0.0048 & $-0.0174^{\star \star \star}$ & 0.0045 \\
\hline Without vocational training & $-0.1017^{\star \star \star}$ & 0.0056 & $-0.0975^{\star \star \star}$ & 0.0051 & $-0.0976^{\star \star \star}$ & 0.0049 \\
\hline Graduate degree & $0.3098^{\star \star \star}$ & 0.0083 & $0.2917^{\star \star \star}$ & 0.0073 & $0.2917^{\star \star \star}$ & 0.0072 \\
\hline Simple blue-collar occupation & $-0.1053^{\star \star \star}$ & 0.0141 & $-0.0910^{\star \star \star}$ & 0.0124 & $-0.0953^{\star \star \star}$ & 0.0115 \\
\hline Qualified blue-collar occupation & $-0.0825^{\star \star \star}$ & 0.0120 & $-0.0884^{\star \star \star}$ & 0.0105 & $-0.0892^{\star \star *}$ & 0.0100 \\
\hline Engineers & 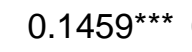 & 0.0169 & $0.1280^{\star * *}$ & 0.0151 & $0.1294^{\star \star \star}$ & 0.0141 \\
\hline Clerical and administrative occupation & $0.1295^{\star \star \star}$ & 0.0113 & $0.1151^{\star * *}$ & 0.0099 & $0.1160^{\star \star \star}$ & 0.0094 \\
\hline Profession, manager and others & $0.2374^{\star \star \star}$ & 0.0102 & $0.2283^{\star \star \star}$ & 0.0088 & $0.2276^{\star \star \star}$ & 0.0085 \\
\hline Employment size $\left(1 / 10^{3}\right)$ & $0.0270^{\star \star *}$ & 0.0032 & $0.0224^{\star \star \star}$ & 0.0027 & $0.0172^{\star \star \star}$ & 0.0026 \\
\hline Employment size squared $\left(1 / 10^{6}\right)$ & $-0.0006^{\star \star *}$ & 0.0001 & $-0.0006^{\star \star \star}$ & 0.0001 & $-0.0004^{\star \star \star}$ & 0.0001 \\
\hline Industry-wide wage agreement & $0.0544^{\star * *}$ & 0.0120 & $0.0586^{\star \star *}$ & 0.0113 & $0.0481^{* \star *}$ & 0.0107 \\
\hline Firm-specific wage agreement & $0.0427^{\star \star}$ & 0.0177 & $0.0475^{\star \star \star}$ & 0.0165 & $0.0300^{\star \star}$ & 0.0145 \\
\hline Works council & $0.1978^{\star \star \star}$ & 0.0168 & $0.1603^{\star * \star}$ & 0.0164 & $0.1319 * \star \star$ & 0.0145 \\
\hline Sales per employee $\left(1 / 10^{5}\right)$ & & & $-0.0002^{\star \star}$ & 0.0001 & $-0.0002^{\star}$ & 0.0001 \\
\hline Wage bill per employee $\left(1 / 10^{4}\right)$ & & & $0.8957^{\star \star *}$ & 0.0865 & $0.8553^{\star \star *}$ & 0.0824 \\
\hline Very high or high state of the technology & & & $0.0172^{\star \star \star}$ & 0.0080 & $0.0168^{\star \star}$ & 0.0079 \\
\hline Average weekly working hours & & & & & $-0.0172^{\star \star \star}$ & 0.0026 \\
\hline Overtime & & & & & $0.0439 * \star \star$ & 0.0110 \\
\hline No overtime compensation & & & & & 0.0233 & 0.0302 \\
\hline Improving work-child compatibility & & & & & $0.0167^{\star \star}$ & 0.0072 \\
\hline Workplace health promotion & & & & & $0.0335^{\star \star \star}$ & 0.0085 \\
\hline Workplace with physical or mental stress & & & & & -0.0051 & 0.0071 \\
\hline Workplace with high flexibility needs & & & & & $0.0198^{\star * *}$ & 0.0066 \\
\hline Region / Industry controls / Interaction terms & yes / ye & es /no & yes / ye & es / no & yes / ye & es / no \\
\hline Log pseudolikelihood & $-29,50$ & 00.68 & $-23,21$ & 11.94 & $-21,81$ & 15.03 \\
\hline Observations & 192,8 & 814 & $192, \varepsilon$ & 814 & $192, \varepsilon$ & 814 \\
\hline
\end{tabular}

Note: The dependent variable is the log of the real daily wage. The results are based on Tobit regressions. Clustered standard errors at the establishment level. The estimated coefficients for the regional, industry controls and interaction terms are available upon request from the author.

Significance levels: *: 10 percent **:5 percent ***: 1 percent

Source: LIAB cross-sectional model 2002. 
Table A 6, continued: Estimates of Tobit wage regressions for female employees, western Germany

\begin{tabular}{|c|c|c|c|c|c|c|}
\hline \multirow[b]{2}{*}{ Variables } & \multicolumn{2}{|c|}{ Specification (7) } & \multicolumn{2}{|c|}{ Specification (8) } & \multicolumn{2}{|c|}{ Specification (9) } \\
\hline & Coeff. & Std. Err. & Coeff. & Std. Err. & Coeff. & Std. Err. \\
\hline Female proportion & $-0.0458^{\star \star}$ & 0.0224 & $-0.1810^{\star * *}$ & 0.0215 & $-0.1896^{\star \star \star}$ & 0.0257 \\
\hline Age & $0.0282^{\star \star \star}$ & 0.0014 & $0.0269 * * \star$ & 0.0016 & $0.0288^{* * *}$ & 0.0016 \\
\hline Age squared $\left(1 / 10^{2}\right)$ & $-0.0312^{\star \star \star}$ & 0.0017 & $-0.0306^{\star * *}$ & 0.0019 & $-0.0318^{* * *}$ & 0.0019 \\
\hline Job tenure (in month) & $0.0009^{\star \star \star}$ & 0.0001 & $0.0010^{\star \star \star}$ & 0.0001 & $0.0009 * \star \star$ & 0.0001 \\
\hline Job tenure squared $\left(1 / 10^{2}\right)$ & $-0.0001^{\star \star \star}$ & 0.0000 & $-0.0001^{\star \star \star}$ & 0.0000 & $-0.0001^{\star * \star}$ & 0.0000 \\
\hline Foreigner & $-0.0175^{\star \star \star}$ & 0.0043 & $-0.0148^{\star \star}$ & 0.0053 & $-0.0128^{\star *}$ & 0.0051 \\
\hline Without vocational training & $0.3361^{\star *}$ & 0.1206 & $-0.1052^{\star \star \star}$ & 0.0057 & $-0.1035^{\star \star \star}$ & 0.0054 \\
\hline Graduate degree & $-0.3013^{*}$ & 0.1561 & $0.3297^{\star \star \star}$ & 0.0085 & $0.3142^{\star \star *}$ & 0.0083 \\
\hline Simple blue-collar occupation & 0.3829 & 0.2880 & $-0.0876^{\star \star \star}$ & 0.0130 & $-0.1102^{\star \star \star}$ & 0.0132 \\
\hline Qualified blue-collar occupation & $0.4586^{*}$ & 0.2734 & $-0.0687^{\star \star \star}$ & 0.0119 & 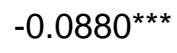 & 0.0111 \\
\hline Engineers & $1.2414^{\star \star \star}$ & 0.3134 & $0.1659 * * *$ & 0.0177 & $0.1455^{\star \star *}$ & 0.0162 \\
\hline Clerical and administrative occupation & $0.8425^{\star \star \star}$ & 0.2878 & $0.1722^{\star * \star}$ & 0.0129 & $0.1272^{\star \star \star}$ & 0.0107 \\
\hline Profession, manager and others & $1.7600^{\star \star \star}$ & 0.3364 & $0.2413^{\star \star \star}$ & 0.0100 & $0.2438^{\star * \star}$ & 0.0099 \\
\hline Employment size $\left(1 / 10^{3}\right)$ & $0.0179^{\star \star *}$ & 0.0024 & & & $0.0225^{\star \star \star}$ & 0.0034 \\
\hline Employment size squared $\left(1 / 10^{6}\right)$ & $-0.0005^{\star \star \star}$ & 0.0001 & & & $-0.0005^{\star \star \star}$ & 0.0001 \\
\hline Industry-wide wage agreement & $0.0478^{* \star \star}$ & 0.0107 & & & & \\
\hline Firm-specific wage agreement & $0.0311^{* *}$ & 0.0142 & & & & \\
\hline Works council & $0.1288^{\star \star *}$ & 0.0147 & & & & \\
\hline Sales per employee $\left(1 / 10^{5}\right)$ & $-0.0002^{*}$ & 0.0001 & & & & \\
\hline Wage bill per employee $\left(1 / 10^{4}\right)$ & $0.8542^{\star \star \star}$ & 0.0816 & & & & \\
\hline Very high or high state of the technology & $0.0164^{\star *}$ & 0.0074 & & & & \\
\hline Average weekly working hours & 0.0000 & 0.0076 & $-0.0249 * \star \star$ & 0.0031 & $-0.0261^{\star \star \star}$ & 0.0037 \\
\hline Overtime & $0.0709^{* \star *}$ & 0.0209 & $0.0861^{\star * *}$ & 0.0131 & $0.0624^{\star \star *}$ & 0.0118 \\
\hline No overtime compensation & 0.0219 & 0.0307 & -0.0389 & 0.0417 & -0.0296 & 0.0312 \\
\hline Improving work-child compatibility & $0.0528^{\star \star \star}$ & 0.0143 & $0.0853^{\star * \star}$ & 0.0110 & $0.0374^{\star \star *}$ & 0.0084 \\
\hline Workplace health promotion & 0.0308 & 0.0190 & $0.0993^{\star * *}$ & 0.0122 & $0.0696^{\star * *}$ & 0.0106 \\
\hline Workplace with physical or mental stress & $0.0342^{\star *}$ & 0.0155 & $-0.0273^{\star *}$ & 0.0101 & $-0.0182^{\star \star}$ & 0.0083 \\
\hline Workplace with high flexibility needs & 0.0171 & 0.0149 & $0.0354^{\star * *}$ & 0.0114 & $0.0272^{\star \star *}$ & 0.0081 \\
\hline Region / Industry controls / Interaction terms & yes / yes & s / yes & yes / ye & es /no & yes / y & es /no \\
\hline Log pseudolikelihood & $-21,05$ & 54.55 & $-37,81$ & 18.12 & $-30,84$ & 47.80 \\
\hline Observations & 192,8 & 814 & 192,8 & 814 & 192, & 814 \\
\hline
\end{tabular}

Note: The dependent variable is the log of the real daily wage. The results are based on Tobit regressions. Clustered standard errors at the establishment level. The estimated coefficients for the regional, industry controls and interaction terms are available upon request from the author.

Significance levels: *: 10 percent $* *: 5$ percent $* * *: 1$ percent

Source: LIAB cross-sectional model 2002. 
Table A 6, continued: Estimates of Tobit wage regressions for female employees, western Germany

\begin{tabular}{|c|c|c|c|c|c|c|}
\hline \multirow[b]{2}{*}{ Variables } & \multicolumn{2}{|c|}{ Specification (10) } & \multicolumn{2}{|c|}{ Specification (11) } & \multicolumn{2}{|c|}{ Specification (12) } \\
\hline & Coeff. & Std. Err. & Coeff. & Std. Err. & Coeff. & Std. Err. \\
\hline Female proportion & $-0.1669 * \star \star$ & 0.0252 & $-0.3069 * * *$ & 0.0333 & $-0.2656^{\star \star \star}$ & 0.0314 \\
\hline Age & $0.0294^{\star \star \star}$ & 0.0016 & & & & \\
\hline Age squared $\left(1 / 10^{2}\right)$ & $-0.0325^{\star \star \star}$ & 0.0018 & & & & \\
\hline Job tenure (in month) & $0.0008^{\star \star \star}$ & 0.0001 & & & & \\
\hline Job tenure squared $\left(1 / 10^{2}\right)$ & $-0.0001^{\star \star *}$ & 0.0000 & & & & \\
\hline Foreigner & $-0.0139 * * *$ & 0.0049 & & & & \\
\hline Without vocational training & $-0.1017^{\star \star *}$ & 0.0054 & & & & \\
\hline Graduate degree & $0.3085^{\star \star \star}$ & 0.0081 & & & & \\
\hline Simple blue-collar occupation & $-0.1100^{\star \star \star}$ & 0.0129 & & & & \\
\hline Qualified blue-collar occupation & $-0.0842^{\star \star \star}$ & 0.0110 & & & & \\
\hline Engineers & $0.1444^{\star \star *}$ & 0.0156 & & & & \\
\hline Clerical and administrative occupation & $0.1289 * \star \star$ & 0.0105 & & & & \\
\hline Profession, manager and others & $0.2359 * * *$ & 0.0096 & & & & \\
\hline Employment size $\left(1 / 10^{3}\right)$ & $0.0210^{* * *}$ & 0.0031 & $0.0389 * \star \star$ & 0.0045 & $0.0317^{\star \star *}$ & 0.0042 \\
\hline Employment size squared $\left(1 / 10^{6}\right)$ & $-0.0004^{\star \star \star}$ & 0.0001 & $-0.0008^{\star \star \star}$ & 0.0001 & $-0.0006^{\star \star \star}$ & 0.0001 \\
\hline Industry-wide wage agreement & $0.0415^{\star \star \star}$ & 0.0112 & & & $0.0626^{\star * *}$ & 0.0150 \\
\hline Firm-specific wage agreement & 0.0208 & 0.0154 & & & 0.0284 & 0.0234 \\
\hline Works council & 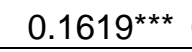 & 0.0147 & & & $0.2270^{* \star \star}$ & 0.0204 \\
\hline \multicolumn{7}{|l|}{ Sales per employee $\left(1 / 10^{5}\right)$} \\
\hline \multicolumn{7}{|l|}{ Wage bill per employee $\left(1 / 10^{4}\right)$} \\
\hline \multicolumn{7}{|l|}{ Very high or high state of the technology } \\
\hline Average weekly working hours & $-0.0192^{\star \star \star}$ & 0.0032 & & & & \\
\hline Overtime & 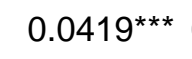 & 0.0113 & & & & \\
\hline No overtime compensation & -0.0104 & 0.0285 & & & & \\
\hline Improving work-child compatibility & $0.0250^{\star \star \star}$ & 0.0082 & & & & \\
\hline Workplace health promotion & $0.0408^{\star \star *}$ & 0.0097 & & & & \\
\hline Workplace with physical or mental stress & -0.0095 & 0.0078 & & & & \\
\hline Workplace with high flexibility needs & $0.0271^{\star * *}$ & 0.0079 & & & & \\
\hline Region / Industry controls / Interaction terms & \multicolumn{2}{|c|}{ yes / yes /no } & \multicolumn{2}{|c|}{ yes / yes / no } & \multicolumn{2}{|c|}{ yes / yes / no } \\
\hline Log pseudolikelihood & \multicolumn{2}{|c|}{$-27,656.16$} & \multicolumn{2}{|c|}{$-67,723.87$} & \multicolumn{2}{|c|}{$-62,615.47$} \\
\hline Observations & \multicolumn{2}{|c|}{192,814} & \multicolumn{2}{|c|}{192,814} & \multicolumn{2}{|c|}{192,814} \\
\hline
\end{tabular}

Note: The dependent variable is the log of the real daily wage. The results are based on Tobit regressions. Clustered standard errors at the establishment level. The estimated coefficients for the regional, industry controls and interaction terms are available upon request from the author.

Significance levels: *: 10 percent $* *: 5$ percent $* * *: 1$ percent

Source: LIAB cross-sectional model 2002. 
Table A 6, continued: Estimates of Tobit wage regressions for female employees, western Germany

\begin{tabular}{|c|c|c|}
\hline & Specification (13) & Specification (14) \\
\hline Variables & Coeff. Std. Err. & Coeff. Std. Err. \\
\hline Female proportion & $-0.0825^{\star \star \star} 0.0290$ & $-0.0816^{\star \star \star} 0.0286$ \\
\hline \multicolumn{3}{|l|}{ Age } \\
\hline \multicolumn{3}{|l|}{ Age squared $\left(1 / 10^{2}\right)$} \\
\hline \multicolumn{3}{|l|}{ Job tenure (in month) } \\
\hline \multicolumn{3}{|l|}{ Job tenure squared $\left(1 / 10^{2}\right)$} \\
\hline \multicolumn{3}{|l|}{ Foreigner } \\
\hline \multicolumn{3}{|l|}{ Without vocational training } \\
\hline \multicolumn{3}{|l|}{ Graduate degree } \\
\hline \multicolumn{3}{|l|}{ Simple blue-collar occupation } \\
\hline \multicolumn{3}{|l|}{ Qualified blue-collar occupation } \\
\hline \multicolumn{3}{|l|}{ Engineers } \\
\hline \multicolumn{3}{|l|}{ Clerical and administrative occupation } \\
\hline \multicolumn{3}{|l|}{ Profession, manager and others } \\
\hline Employment size $\left(1 / 10^{3}\right)$ & $0.0255^{\star \star \star} 0.0035$ & $0.0204^{\star \star \star} 0.0034$ \\
\hline Employment size squared $\left(1 / 10^{6}\right)$ & $-0.0006^{\star \star \star} 0.0001$ & $-0.0005^{\star \star \star} 0.0001$ \\
\hline Industry-wide wage agreement & $0.0678^{* \star *} 0.0138$ & $0.0578^{\star \star \star} 0.0137$ \\
\hline Firm-specific wage agreement & $0.0348^{*} \quad 0.0194$ & $0.0195 \quad 0.0182$ \\
\hline Works council & $0.1771^{\star \star \star} 0.0197$ & $0.1531^{\star \star \star} 0.0185$ \\
\hline Sales per employee $\left(1 / 10^{5}\right)$ & $-0.0004^{* *} 0.0002$ & $-0.0003^{\star *} 0.0001$ \\
\hline Wage bill per employee $\left(1 / 10^{4}\right)$ & $1.1962^{\star \star \star} 0.1131$ & $1.1590^{\star \star \star} 0.1099$ \\
\hline Very high or high state of the technology & $0.0197^{* *} 0.0096$ & $0.0183^{*} 0.0100$ \\
\hline Average weekly working hours & & $-0.0120 * * * 0.0040$ \\
\hline Overtime & & $0.0496^{\star \star \star} 0.0143$ \\
\hline No overtime compensation & & $0.0518 \quad 0.0347$ \\
\hline Improving work-child compatibility & & $0.0264^{\star \star \star} 0.0096$ \\
\hline Workplace health promotion & & $0.0222^{\star *} 0.0101$ \\
\hline Workplace with physical or mental stress & & $-0.0037 \quad 0.0096$ \\
\hline Workplace with high flexibility needs & & $0.0283^{\star \star \star} 0.0082$ \\
\hline Region / Industry controls / Interaction terms & yes / yes / no & yes / yes / no \\
\hline Log pseudolikelihood & $-54,275.75$ & $-53,369.50$ \\
\hline Observations & 192,814 & 192,814 \\
\hline
\end{tabular}

Note: The dependent variable is the log of the real daily wage. The results are based on Tobit regressions. Clustered standard errors at the establishment level. The estimated coefficients for the regional, industry controls and interaction terms are available upon request from the author.

Significance levels: *: 10 percent $* *: 5$ percent $* * *: 1$ percent

Source: LIAB cross-sectional model 2002. 
Table A 7, continued: Estimates of Tobit wage regressions for male employees, eastern Germany

\begin{tabular}{|c|c|c|c|c|c|c|}
\hline \multirow[b]{2}{*}{ Variables } & \multicolumn{2}{|c|}{ Specification (7) } & \multicolumn{2}{|c|}{ Specification (8) } & \multicolumn{2}{|c|}{ Specification (9) } \\
\hline & Coeff. & Std. Err. & Coeff. & Std. Err. & Coeff. & Std. Err. \\
\hline Female proportion & $-0.0703^{\star \star}$ & 0.0329 & $-0.0675^{\star}$ & 0.0414 & $-0.1354^{\star \star \star}$ & 0.0324 \\
\hline Age & $0.0293^{\star \star \star}$ & 0.0022 & $0.0294^{\star * *}$ & 0.0023 & $0.0311^{* * *}$ & 0.0024 \\
\hline Age squared $\left(1 / 10^{2}\right)$ & $-0.0342^{\star \star \star}$ & 0.0026 & $-0.0356^{\star * *}$ & 0.0025 & $-0.0368^{* * *}$ & 0.0027 \\
\hline Job tenure (in month) & $0.0030^{\star \star \star}$ & 0.0003 & $0.0048^{\star \star \star}$ & 0.0008 & $0.0035^{\star \star \star}$ & 0.0003 \\
\hline Job tenure squared $\left(1 / 10^{2}\right)$ & $-0.0011^{\star \star \star}$ & 0.0002 & $-0.0020^{\star \star \star}$ & 0.0006 & $-0.0012^{\star \star \star}$ & 0.0002 \\
\hline Foreigner & 0.0093 & 0.0118 & 0.0176 & 0.0148 & $0.0296 * \star$ & 0.0136 \\
\hline Without vocational training & -0.3468 & 0.2717 & $-0.0780^{* \star *}$ & 0.0126 & 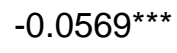 & 0.0117 \\
\hline Graduate degree & -0.2246 & 0.2698 & $0.3792^{\star \star \star}$ & 0.0134 & $0.3399 * \star *$ & 0.0133 \\
\hline Simple blue-collar occupation & $1.0842^{\star \star \star}$ & 0.2869 & 0.0170 & 0.0196 & -0.0135 & 0.0143 \\
\hline Qualified blue-collar occupation & $0.9474^{\star \star \star}$ & 0.2365 & 0.0168 & 0.0123 & 0.0129 & 0.0120 \\
\hline Engineers & $1.4793^{\star \star \star}$ & 0.4113 & $0.2262^{\star \star *}$ & 0.0167 & $0.2250 * \star *$ & 0.0180 \\
\hline Clerical and administrative occupation & $0.8075^{\star \star \star}$ & 0.2870 & $0.2352^{\star * *}$ & 0.0220 & $0.2122^{\star \star *}$ & 0.0178 \\
\hline Profession, manager and others & $0.9394^{\star *}$ & 0.3883 & 0.2040 *** & 0.0203 & $0.2510^{* \star \star}$ & 0.0208 \\
\hline Employment size $\left(1 / 10^{3}\right)$ & $0.0547^{\star \star \star}$ & 0.0175 & & & $0.1134^{\star \star \star}$ & 0.0187 \\
\hline Employment size squared $\left(1 / 10^{6}\right)$ & -0.0035 & 0.0023 & & & $-0.0082^{\star \star \star}$ & 0.0027 \\
\hline Industry-wide wage agreement & $0.0708^{\star \star \star}$ & 0.0126 & & & & \\
\hline Firm-specific wage agreement & 0.0077 & 0.0157 & & & & \\
\hline Works council & $0.0964^{\star \star *}$ & 0.0147 & & & & \\
\hline Sales per employee $\left(1 / 10^{5}\right)$ & $0.0038^{*}$ & 0.0021 & & & & \\
\hline Wage bill per employee $\left(1 / 10^{4}\right)$ & $0.7730^{\star *}$ & 0.3379 & & & & \\
\hline Very high or high state of the technology & $0.0343^{\star \star \star}$ & 0.0099 & & & & \\
\hline Average weekly working hours & $-0.0071^{\star \star}$ & 0.0034 & $-0.0372^{\star \star \star}$ & 0.0066 & $-0.0326^{\star \star \star}$ & 0.0053 \\
\hline Overtime & $0.1120^{* \star *}$ & 0.0324 & $0.1088^{\star * *}$ & 0.0238 & $0.0754^{\star \star *}$ & 0.0180 \\
\hline No overtime compensation & $0.1073^{\star *}$ & 0.0509 & 0.0250 & 0.0785 & 0.1107 & 0.0849 \\
\hline Improving work-child compatibility & $0.0381^{*}$ & 0.0201 & $0.0686^{\star * \star}$ & 0.0201 & $0.0284^{\star \star}$ & 0.0159 \\
\hline Workplace health promotion & -0.0272 & 0.0214 & $0.1038^{\star * *}$ & 0.0209 & $0.0572^{* * *}$ & 0.0131 \\
\hline Workplace with physical or mental stress & -0.0235 & 0.0179 & $-0.0379 * *$ & 0.0199 & -0.0152 & 0.0120 \\
\hline Workplace with high flexibility needs & 0.0001 & 0.0157 & -0.0175 & 0.0281 & 0.0062 & 0.0111 \\
\hline Region / Industry controls / Interaction terms & yes / ye & es / no & yes / ye & es / no & yes / ye & es / no \\
\hline Log pseudolikelihood & 6,757 & 7.33 & $-15,66$ & 68.79 & $-4,27$ & 6.65 \\
\hline Observations & 120,9 & 985 & $120, \mathrm{c}$ & 985 & 120 & 985 \\
\hline
\end{tabular}

Note: The dependent variable is the log of the real daily wage. The results are based on Tobit regressions. Clustered standard errors at the establishment level. The estimated coefficients for the regional, industry controls and interaction terms are available upon request from the author.

Significance levels: *: 10 percent **:5 percent ***: 1 percent

Source: LIAB cross-sectional model 2002. 
Table A 7: Estimates of Tobit wage regressions for male employees, eastern Germany

\begin{tabular}{|c|c|c|c|c|c|}
\hline \multirow[b]{2}{*}{ Variables } & Specification (1) & \multicolumn{2}{|c|}{ Specification (2) } & \multicolumn{2}{|c|}{ Specification (3) } \\
\hline & Coeff. Std. Err. & Coeff. & Std. Err & Coeff. & Std. Err. \\
\hline Female proportion & $0.1717^{\star \star \star} 0.0567$ & $-0.0889 *$ & 0.0458 & $-0.1413^{\star \star \star}$ & 0.0331 \\
\hline Age & & $0.0307^{\star \star *}$ & 0.0025 & $0.0324^{\star \star *}$ & 0.0025 \\
\hline Age squared $\left(1 / 10^{2}\right)$ & & $-0.0376^{\star * *}$ & 0.0027 & $-0.0385^{\star \star *}$ & 0.0029 \\
\hline Job tenure (in month) & & $0.0048^{\star \star *}$ & 0.0009 & $0.0035^{\star \star *}$ & 0.0004 \\
\hline Job tenure squared $\left(1 / 10^{2}\right)$ & & $-0.0018^{\star \star \star}$ & 0.0007 & $-0.0011^{\star \star *}$ & 0.0002 \\
\hline Foreigner & & 0.0269 & 0.0170 & $0.0321^{\star \star}$ & 0.0147 \\
\hline Without vocational training & & $-0.0748^{\star \star \star}$ & 0.0126 & $-0.0521^{\star \star \star}$ & 0.0112 \\
\hline Graduate degree & & $0.4060 * \star \star$ & 0.0148 & 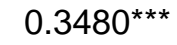 & 0.0140 \\
\hline Simple blue-collar occupation & & 0.0352 & 0.0227 & -0.0066 & 0.0148 \\
\hline Qualified blue-collar occupation & & $0.0308^{\star \star}$ & 0.0139 & $0.0229 *$ & 0.0127 \\
\hline Engineers & & $0.2406^{\star \star \star}$ & 0.0176 & $0.2331^{\star \star *}$ & 0.0184 \\
\hline Clerical and administrative occupation & & $0.2459 * \star \star$ & 0.0214 & $0.2193^{\star \star *}$ & 0.0168 \\
\hline Profession, manager and others & & $0.1884^{\star \star \star}$ & 0.0212 & $0.2575^{\star \star \star}$ & 0.0218 \\
\hline Employment size $\left(1 / 10^{3}\right)$ & & & & $0.1587^{\star \star \star}$ & 0.0211 \\
\hline Employment size squared $\left(1 / 10^{6}\right)$ & & & & $-0.0150 * \star \star$ & 0.0030 \\
\hline
\end{tabular}

Industry-wide wage agreement

Firm-specific wage agreement

Works council

Sales per employee $\left(1 / 10^{5}\right)$

Wage bill per employee $\left(1 / 10^{4}\right)$

Very high or high state of the technology

Average weekly working hours

Overtime

No overtime compensation

Improving work-child compatibility

Workplace health promotion

Workplace with physical or mental stress

Workplace with high flexibility needs

\begin{tabular}{lccc}
\hline Region / Industry controls / Interaction terms & no / no / no & yes / no /no & yes / yes / no \\
Log pseudolikelihood & $-54,723.55$ & $-22,515.08$ & $-7,955.87$ \\
\hline Observations & 120,985 & 120,985 & 120,985 \\
\hline
\end{tabular}

Note: The dependent variable is the log of the real daily wage. The results are based on Tobit regressions. Clustered standard errors at the establishment level. The estimated coefficients for the regional, industry controls and interaction terms are available upon request from the author.

Significance levels: *: 10 percent $* *: 5$ percent $* * *: 1$ percent

Source: LIAB cross-sectional model 2002. 
Table A 7, continued: Estimates of Tobit wage regressions for male employees, eastern Germany

\begin{tabular}{|c|c|c|c|c|c|c|}
\hline \multirow[b]{2}{*}{ Variables } & \multicolumn{2}{|c|}{ Specification (4) } & \multicolumn{2}{|c|}{ Specification (5) } & \multicolumn{2}{|c|}{ Specification (6) } \\
\hline & Coeff. & Std. Err. & Coeff. & Std. Err. & Coeff. & Std. Err. \\
\hline Female proportion & $-0.1293^{\star \star \star}$ & 0.0325 & $-0.0684^{*}$ & 0.0351 & $-0.0728^{\star \star}$ & 0.0345 \\
\hline Age & $0.0311^{\star * *}$ & 0.0023 & $0.0303^{\star \star *}$ & 0.0023 & $0.0301^{\star \star *}$ & 0.0022 \\
\hline Age squared $\left(1 / 10^{2}\right)$ & $-0.0369^{\star \star \star}$ & 0.0027 & $-0.0355^{\star \star *}$ & 0.0027 & $-0.0351^{* * *}$ & 0.0026 \\
\hline Job tenure (in month) & $0.0033^{\star \star \star}$ & 0.0003 & $0.0030 * \star \star$ & 0.0003 & $0.0031^{* \star *}$ & 0.0003 \\
\hline Job tenure squared $\left(1 / 10^{2}\right)$ & $-0.0013^{\star \star \star}$ & 0.0002 & $-0.0011^{\star \star \star}$ & 0.0002 & $-0.0012^{\star \star \star}$ & 0.0002 \\
\hline Foreigner & 0.0121 & 0.0131 & 0.0057 & 0.0129 & 0.0078 & 0.0126 \\
\hline Without vocational training & $-0.0485^{\star \star \star}$ & 0.0100 & $-0.0456^{\star \star \star}$ & 0.0092 & $-0.0482^{\star \star \star}$ & 0.0093 \\
\hline Graduate degree & $0.3233^{\star \star \star}$ & 0.0129 & $0.2968^{\star \star \star}$ & 0.0147 & $0.2969 * \star \star *$ & 0.0140 \\
\hline Simple blue-collar occupation & -0.0010 & 0.0137 & -0.0076 & 0.0115 & -0.0098 & 0.0115 \\
\hline Qualified blue-collar occupation & $0.0369 * \star \star$ & 0.0117 & $0.0275^{\star \star \star}$ & 0.0099 & $0.0222^{\star \star}$ & 0.0097 \\
\hline Engineers & $0.2445^{\star \star \star}$ & 0.0178 & $0.2348^{\star * *}$ & 0.0158 & $0.2311^{* * *}$ & 0.0159 \\
\hline Clerical and administrative occupation & $0.2356^{\star \star \star}$ & 0.0167 & $0.2242^{\star * *}$ & 0.0158 & $0.2204^{\star * *}$ & 0.0167 \\
\hline Profession, manager and others & $0.2697^{\star \star *}$ & 0.0197 & $0.2618^{\star \star \star}$ & 0.0181 & $0.2581^{\star \star *}$ & 0.0179 \\
\hline Employment size $\left(1 / 10^{3}\right)$ & $0.0857^{\star \star \star}$ & 0.0202 & 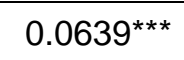 & 0.0195 & $0.0582^{\star \star \star}$ & 0.0187 \\
\hline Employment size squared $\left(1 / 10^{6}\right)$ & $-0.0067^{\star \star}$ & 0.0028 & $-0.0057^{\star *}$ & 0.0025 & $-0.0044^{*}$ & 0.0024 \\
\hline Industry-wide wage agreement & $0.1047^{\star \star *}$ & 0.0152 & $0.0824 * \star \star$ & 0.0143 & $0.0743^{\star * \star}$ & 0.0132 \\
\hline Firm-specific wage agreement & 0.0263 & 0.0204 & 0.0185 & 0.0174 & 0.0080 & 0.0167 \\
\hline Works council & $0.1525^{\star \star \star}$ & 0.0153 & $0.1142^{\star \star \star}$ & 0.0164 & $0.1010 * \star \star$ & 0.0152 \\
\hline Sales per employee $\left(1 / 10^{5}\right)$ & & & $0.0039^{*}$ & 0.0022 & $0.0038^{*}$ & 0.0021 \\
\hline Wage bill per employee $\left(1 / 10^{4}\right)$ & & & $0.8292^{\star *}$ & 0.3557 & $0.7830^{\star *}$ & 0.3429 \\
\hline Very high or high state of the technology & & & $0.0307^{\star \star \star}$ & 0.0107 & $0.0312^{\star \star \star}$ & 0.0105 \\
\hline Average weekly working hours & & & & & $-0.0174^{* \star *}$ & 0.0040 \\
\hline Overtime & & & & & $0.0499^{\star \star \star}$ & 0.0150 \\
\hline No overtime compensation & & & & & $0.1085^{\star \star}$ & 0.0550 \\
\hline Improving work-child compatibility & & & & & -0.0024 & 0.0130 \\
\hline Workplace health promotion & & & & & 0.0111 & 0.0109 \\
\hline Workplace with physical or mental stress & & & & & -0.0139 & 0.0106 \\
\hline Workplace with high flexibility needs & & & & & 0.0100 & 0.0091 \\
\hline Region / Industry controls / Interaction terms & yes / ye & es/no & yes / ye & es / no & yes / ye & es / no \\
\hline Log pseudolikelihood & $-1,089$ & 9.98 & 4,533 & 3.63 & 5,75 & 2.97 \\
\hline Observations & 120,9 & 985 & $120, \subseteq$ & 985 & 120 & 985 \\
\hline
\end{tabular}

Note: The dependent variable is the log of the real daily wage. The results are based on Tobit regressions. Clustered standard errors at the establishment level. The estimated coefficients for the regional, industry controls and interaction terms are available upon request from the author.

Significance levels: *: 10 percent $* *: 5$ percent $* * *: 1$ percent

Source: LIAB cross-sectional model 2002. 
Table A 7, continued: Estimates of Tobit wage regressions for male employees, eastern Germany

\begin{tabular}{|c|c|c|c|c|c|c|}
\hline \multirow[b]{2}{*}{ Variables } & \multicolumn{2}{|c|}{ Specification (10) } & \multicolumn{2}{|c|}{ Specification (11) } & \multicolumn{2}{|c|}{ Specification (12) } \\
\hline & Coeff. & Std. Err. & Coeff. & Std. Err. & Coeff. & Std. Err. \\
\hline Female proportion & $-0.1296^{\star \star \star}$ & 0.0318 & -0.0054 & 0.0424 & 0.0109 & 0.0418 \\
\hline Age & $0.0307^{* * *}$ & 0.0023 & & & & \\
\hline Age squared $\left(1 / 10^{2}\right)$ & $-0.0362^{* \star *}$ & 0.0027 & & & & \\
\hline Job tenure (in month) & $0.0034^{\star \star \star}$ & 0.0003 & & & & \\
\hline Job tenure squared $\left(1 / 10^{2}\right)$ & $-0.0013^{\star * *}$ & 0.0002 & & & & \\
\hline Foreigner & 0.0127 & 0.0125 & & & & \\
\hline Without vocational training & $-0.0515^{\star \star \star}$ & 0.0104 & & & & \\
\hline Graduate degree & $0.3197^{\star \star \star}$ & 0.0123 & & & & \\
\hline Simple blue-collar occupation & -0.0047 & 0.0134 & & & & \\
\hline Qualified blue-collar occupation & $0.0289 * \star$ & 0.0113 & & & & \\
\hline Engineers & 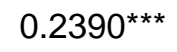 & 0.0176 & & & & \\
\hline Clerical and administrative occupation & $0.2296^{\star * *}$ & 0.0179 & & & & \\
\hline Profession, manager and others & $0.2649 * \star *$ & 0.0192 & & & & \\
\hline Employment size $\left(1 / 10^{3}\right)$ & $0.0707^{\star \star \star}$ & 0.0194 & $0.2432^{\star \star \star}$ & 0.0254 & $0.1445^{\star \star \star}$ & 0.0249 \\
\hline Employment size squared $\left(1 / 10^{6}\right)$ & -0.0041 & 0.0028 & $-0.0283^{\star \star *}$ & 0.0037 & $-0.0165^{\star \star \star}$ & 0.0035 \\
\hline Industry-wide wage agreement & $0.0925^{\star * *}$ & 0.0138 & & & $0.1172^{\star \star *}$ & 0.0186 \\
\hline Firm-specific wage agreement & 0.0133 & 0.0193 & & & 0.0340 & 0.0261 \\
\hline Works council & $0.1332^{\star \star \star}$ & 0.0141 & & & $0.2025^{\star * \star}$ & 0.0183 \\
\hline \multicolumn{7}{|l|}{ Sales per employee $\left(1 / 10^{5}\right)$} \\
\hline \multicolumn{7}{|l|}{ Wage bill per employee $\left(1 / 10^{4}\right)$} \\
\hline \multicolumn{7}{|l|}{ Very high or high state of the technology } \\
\hline Average weekly working hours & $-0.0198^{\star \star \star}$ & 0.0044 & & & & \\
\hline Overtime & $0.0667^{\star \star \star}$ & 0.0165 & & & & \\
\hline No overtime compensation & $0.1422^{\star * *}$ & 0.0694 & & & & \\
\hline Improving work-child compatibility & 0.0148 & 0.0150 & & & & \\
\hline Workplace health promotion & 0.0190 & 0.0117 & & & & \\
\hline Workplace with physical or mental stress & $-0.0209 * \star$ & 0.0112 & & & & \\
\hline Workplace with high flexibility needs & 0.0130 & 0.0103 & & & & \\
\hline Region / Industry controls / Interaction terms & \multicolumn{2}{|c|}{ yes / yes / no } & \multicolumn{2}{|c|}{ yes / yes / no } & \multicolumn{2}{|c|}{ yes / yes / no } \\
\hline Log pseudolikelihood & \multicolumn{2}{|c|}{695.00} & \multicolumn{2}{|c|}{$-42,504.92$} & \multicolumn{2}{|c|}{$-36,065.71$} \\
\hline Observations & \multicolumn{2}{|c|}{120,985} & \multicolumn{2}{|c|}{120,985} & \multicolumn{2}{|c|}{120,985} \\
\hline
\end{tabular}

Note: The dependent variable is the log of the real daily wage. The results are based on Tobit regressions. Clustered standard errors at the establishment level. The estimated coefficients for the regional, industry controls and interaction terms are available upon request from the author.

Significance levels: *: 10 percent $* *: 5$ percent $* * *: 1$ percent

Source: LIAB cross-sectional model 2002. 
Table A 7, continued: Estimates of Tobit wage regressions for male employees, eastern Germany

\begin{tabular}{|c|c|c|c|}
\hline \multirow[b]{2}{*}{ Variables } & Specification (13) & \multicolumn{2}{|c|}{ Specification (14) } \\
\hline & Coeff. Std. Err. & Coeff. & Std. Err. \\
\hline Female proportion & $0.0889^{* *} 0.0434$ & $0.0804^{*}$ & 0.0427 \\
\hline \multicolumn{4}{|l|}{ Age } \\
\hline \multicolumn{4}{|l|}{ Age squared $\left(1 / 10^{2}\right)$} \\
\hline \multicolumn{4}{|l|}{ Job tenure (in month) } \\
\hline \multicolumn{4}{|l|}{ Job tenure squared $\left(1 / 10^{2}\right)$} \\
\hline \multicolumn{4}{|l|}{ Foreigner } \\
\hline \multicolumn{4}{|l|}{ Without vocational training } \\
\hline \multicolumn{4}{|l|}{ Graduate degree } \\
\hline \multicolumn{4}{|l|}{ Simple blue-collar occupation } \\
\hline \multicolumn{4}{|l|}{ Qualified blue-collar occupation } \\
\hline \multicolumn{4}{|l|}{ Engineers } \\
\hline \multicolumn{4}{|l|}{ Clerical and administrative occupation } \\
\hline \multicolumn{4}{|l|}{ Profession, manager and others } \\
\hline Employment size $\left(1 / 10^{3}\right)$ & $0.1106^{* \star \star} 0.0233$ & $0.1004^{\star \star \star}$ & *0.0227 \\
\hline Employment size squared $\left(1 / 10^{6}\right)$ & $-0.0144^{\star \star \star} 0.0029$ & $-0.0125^{\star \star \star}$ & *0.0029 \\
\hline Industry-wide wage agreement & $0.0834^{\star \star \star} 0.0183$ & $0.0749 * * *$ & * 0.0169 \\
\hline Firm-specific wage agreement & $0.0214 \quad 0.0219$ & 0.0100 & 0.0207 \\
\hline Works council & $0.1454^{* \star *} 0.0213$ & $0.1372^{\star * *}$ & *0.0196 \\
\hline Sales per employee $\left(1 / 10^{5}\right)$ & $0.0043^{*} 0.0023$ & $0.0040^{*}$ & 0.0021 \\
\hline Wage bill per employee $\left(1 / 10^{4}\right)$ & $1.1717^{* *} 0.4995$ & $1.1071^{* *}$ & 0.4841 \\
\hline Very high or high state of the technology & $0.0341^{* \star \star} 0.0130$ & $0.0344^{\star \star \star}$ & *0.0128 \\
\hline Average weekly working hours & & $-0.0147^{* * \star}$ & *0.0044 \\
\hline Overtime & & $0.0551^{* * *}$ & *0.0182 \\
\hline No overtime compensation & & $0.1641^{\star *}$ & 0.0771 \\
\hline Improving work-child compatibility & & 0.0107 & 0.0167 \\
\hline Workplace health promotion & & 0.0070 & 0.0127 \\
\hline Workplace with physical or mental stress & & $-0.0323^{\star *}$ & 0.0136 \\
\hline Workplace with high flexibility needs & & $0.0191^{*}$ & 0.0106 \\
\hline Region / Industry controls / Interaction terms & yes / yes / no & yes / ye & es/no \\
\hline Log pseudolikelihood & $-29,625.48$ & $-28,71$ & 17.36 \\
\hline Observations & 120,985 & 120 & 985 \\
\hline
\end{tabular}

Note: The dependent variable is the log of the real daily wage. The results are based on Tobit regressions. Clustered standard errors at the establishment level. The estimated coefficients for the regional, industry controls and interaction terms are available upon request from the author.

Significance levels: *: 10 percent $* *: 5$ percent $* * *: 1$ percent

Source: LIAB cross-sectional model 2002. 
Table A 8: Estimates of Tobit wage regressions for female employees, eastern Germany

\begin{tabular}{|c|c|c|c|c|c|}
\hline \multirow[b]{2}{*}{ Variables } & \multirow{2}{*}{$\begin{array}{l}\text { Specification (1) } \\
\text { Coeff. Std. Err. }\end{array}$} & \multicolumn{2}{|c|}{ Specification (2) } & \multicolumn{2}{|c|}{ Specification (3) } \\
\hline & & Coeff. & Std. Err. & Coeff. & Std. Err. \\
\hline Female proportion & -0.00990 .0567 & -0.0819 & 0.0556 & $-0.2452^{\star * \star}$ & 0.0399 \\
\hline Age & & $0.0383^{\star \star \star}$ & 0.0039 & $0.0412^{\star \star \star}$ & 0.0032 \\
\hline Age squared $\left(1 / 10^{2}\right)$ & & $-0.0453^{* * *}$ & 0.0038 & $-0.0483^{\star \star \star}$ & 0.0036 \\
\hline Job tenure (in month) & & $0.0051^{\star \star \star}$ & 0.0009 & $0.0040^{* * *}$ & 0.0005 \\
\hline Job tenure squared $\left(1 / 10^{2}\right)$ & & $-0.0018^{\star *}$ & 0.0007 & $-0.0012^{\star \star *}$ & 0.0004 \\
\hline Foreigner & & 0.0623 & 0.0425 & 0.0546 & 0.0374 \\
\hline Without vocational training & & $-0.0621^{\star \star *}$ & 0.0210 & $-0.0504^{* * *}$ & 0.0185 \\
\hline Graduate degree & & $0.3296^{* \star \star}$ & 0.0145 & $0.2941^{\star \star \star}$ & 0.0125 \\
\hline Simple blue-collar occupation & & $-0.0757^{* *}$ & 0.0323 & -0.0384 & 0.0249 \\
\hline Qualified blue-collar occupation & & $-0.0544^{\star}$ & 0.0290 & -0.0348 & 0.0223 \\
\hline Engineers & & $0.1827^{\star \star \star}$ & 0.0289 & $0.1670^{\star \star \star}$ & 0.0247 \\
\hline Clerical and administrative occupation & & $0.1964^{\star \star \star}$ & 0.0386 & $0.1575^{\star \star \star}$ & 0.0238 \\
\hline Profession, manager and others & & $0.2735^{\star \star \star}$ & 0.0238 & $0.2727^{\star \star \star}$ & 0.0240 \\
\hline Employment size $\left(1 / 10^{3}\right)$ & & & & $0.1702^{\star \star *}$ & 0.0307 \\
\hline Employment size squared $\left(1 / 10^{6}\right)$ & & & & $-0.0187^{\star \star}$ & 0.0075 \\
\hline
\end{tabular}

Industry-wide wage agreement

Firm-specific wage agreement

Works council

Sales per employee $\left(1 / 10^{5}\right)$

Wage bill per employee $\left(1 / 10^{4}\right)$

Very high or high state of the technology

Average weekly working hours

Overtime

No overtime compensation

Improving work-child compatibility

Workplace health promotion

Workplace with physical or mental stress

Workplace with high flexibility needs

Region / Industry controls / Interaction terms

Log pseudolikelihood

no / no / no
$-37,926.55$

75,340

yes / no / no
$-20,080.85$

75,340

yes / yes / no $-11,633.91$

Note: The dependent variable is the log of the real daily wage. The results are based on Tobit regressions. Clustered standard errors at the establishment level. The estimated coefficients for the regional, industry controls and interaction terms are available upon request from the author.

Significance levels: *: 10 percent $* *: 5$ percent ${ }^{* * *}$ : 1 percent

Source: LIAB cross-sectional model 2002. 
Table A 8, continued: Estimates of Tobit wage regressions for female employees, eastern Germany

\begin{tabular}{|c|c|c|c|c|c|c|}
\hline \multirow[b]{2}{*}{ Variables } & \multicolumn{2}{|c|}{ Specification (4) } & \multicolumn{2}{|c|}{ Specification (5) } & \multicolumn{2}{|c|}{ Specification (6) } \\
\hline & Coeff. & Std. Err. & Coeff. & Std. Err. & Coeff. & Std. Err. \\
\hline Female proportion & $-0.1993^{\star \star \star}$ & 0.0338 & $-0.1202^{\star \star *}$ & 0.0330 & $-0.1203^{\star \star *}$ & 0.0321 \\
\hline Age & $0.0388^{\star \star \star}$ & 0.0029 & 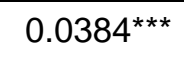 & 0.0026 & $0.0384^{\star \star *}$ & 0.0026 \\
\hline Age squared $\left(1 / 10^{2}\right)$ & $-0.0448^{\star \star \star}$ & 0.0032 & $-0.0438^{* \star *}$ & 0.0029 & $-0.0438^{* * *}$ & 0.0029 \\
\hline Job tenure (in month) & $0.0036^{\star \star \star}$ & 0.0004 & $0.0033^{\star * *}$ & 0.0004 & $0.0033^{* * *}$ & 0.0004 \\
\hline Job tenure squared $\left(1 / 10^{2}\right)$ & $-0.0013^{\star \star \star}$ & 0.0003 & $-0.0013^{\star \star *}$ & 0.0002 & $-0.0013^{* * *}$ & 0.0003 \\
\hline Foreigner & 0.0287 & 0.0273 & 0.0232 & 0.0280 & 0.0231 & 0.0247 \\
\hline Without vocational training & $-0.0414^{\star \star}$ & 0.0169 & $-0.0327^{\star \star}$ & 0.0160 & $-0.0392^{\star \star \star}$ & 0.0149 \\
\hline Graduate degree & $0.2823^{\star \star \star}$ & 0.0110 & $0.2672^{\star \star \star}$ & 0.0111 & 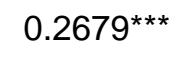 & 0.0106 \\
\hline Simple blue-collar occupation & $-0.0386^{*}$ & 0.0212 & $-0.0366^{*}$ & 0.0187 & -0.0277 & 0.0183 \\
\hline Qualified blue-collar occupation & $-0.0379^{\star \star}$ & 0.0191 & $-0.0430 * \star$ & 0.0170 & $-0.0372^{\star \star}$ & 0.0170 \\
\hline Engineers & $0.1747^{\star \star *}$ & 0.0231 & $0.1674^{\star \star \star}$ & 0.0207 & $0.1782^{\star \star \star}$ & 0.0209 \\
\hline Clerical and administrative occupation & $0.1623^{\star \star *}$ & 0.0202 & 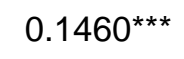 & 0.0179 & $0.1519 * \star *$ & 0.0183 \\
\hline Profession, manager and others & $0.2509 * * *$ & 0.0200 & $0.2386^{\star \star \star}$ & 0.0190 & $0.2402^{\star * *}$ & 0.0191 \\
\hline Employment size $\left(1 / 10^{3}\right)$ & $0.0805^{\star \star \star}$ & 0.0246 & $0.0589 * \star \star$ & 0.0209 & $0.0580 * * *$ & 0.0214 \\
\hline Employment size squared $\left(1 / 10^{6}\right)$ & -0.0069 & 0.0053 & -0.0054 & 0.0042 & -0.0049 & 0.0042 \\
\hline Industry-wide wage agreement & $0.1228^{\star \star \star}$ & 0.0241 & $0.1003^{\star * \star}$ & 0.0232 & $0.0976^{* * *}$ & 0.0220 \\
\hline Firm-specific wage agreement & 0.0144 & 0.0282 & 0.0161 & 0.0239 & 0.0130 & 0.0227 \\
\hline Works council & $0.2395^{\star \star \star}$ & 0.0238 & $0.1870^{\star \star \star}$ & 0.0253 & $0.1701^{\star \star \star}$ & 0.0245 \\
\hline Sales per employee $\left(1 / 10^{5}\right)$ & & & 0.0004 & 0.0008 & 0.0004 & 0.0008 \\
\hline Wage bill per employee $\left(1 / 10^{4}\right)$ & & & $1.0434^{\star \star \star}$ & 0.3409 & $1.0356^{\star \star *}$ & 0.3489 \\
\hline Very high or high state of the technology & & & 0.0146 & 0.0127 & 0.0119 & 0.0127 \\
\hline Average weekly working hours & & & & & $-0.0208^{\star \star \star}$ & 0.0054 \\
\hline Overtime & & & & & $0.0300^{\star *}$ & 0.0138 \\
\hline No overtime compensation & & & & & 0.0467 & 0.0668 \\
\hline Improving work-child compatibility & & & & & -0.0098 & 0.0138 \\
\hline Workplace health promotion & & & & & 0.0218 & 0.0141 \\
\hline Workplace with physical or mental stress & & & & & 0.0114 & 0.0133 \\
\hline Workplace with high flexibility needs & & & & & 0.0009 & 0.0126 \\
\hline Region / Industry controls / Interaction terms & yes / ye & es / no & yes / ye & es / no & yes / ye & es / no \\
\hline Log pseudolikelihood & $-5,249$ & 9.51 & & 4.62 & $-1,62$ & 6.10 \\
\hline Observations & 75,3 & 340 & 75,3 & 340 & & 340 \\
\hline
\end{tabular}

Note: The dependent variable is the log of the real daily wage. The results are based on Tobit regressions. Clustered standard errors at the establishment level. The estimated coefficients for the regional, industry controls and interaction terms are available upon request from the author.

Significance levels: *: 10 percent $* *: 5$ percent $* * *: 1$ percent

Source: LIAB cross-sectional model 2002. 
Table A 8, continued: Estimates of Tobit wage regressions for female employees, eastern Germany

\begin{tabular}{|c|c|c|c|c|c|c|}
\hline \multirow[b]{2}{*}{ Variables } & \multicolumn{2}{|c|}{ Specification (7) } & \multicolumn{2}{|c|}{ Specification (8) } & \multicolumn{2}{|c|}{ Specification (9) } \\
\hline & Coeff. & Std. Err. & Coeff. & Std. Err. & Coeff. & Std. Err. \\
\hline Female proportion & $-0.1209 * \star *$ & 0.0309 & -0.0442 & 0.0462 & $-0.2231^{\star \star \star}$ & 0.0387 \\
\hline Age & $0.0372^{\star \star \star}$ & 0.0023 & $0.0394 * \star \star$ & 0.0034 & $0.0416^{\star \star \star}$ & 0.0033 \\
\hline Age squared $\left(1 / 10^{2}\right)$ & $-0.0423^{\star \star *}$ & 0.0027 & $-0.0462^{\star * *}$ & 0.0036 & $-0.0484^{* * *}$ & 0.0037 \\
\hline Job tenure (in month) & $0.0032^{\star \star \star}$ & 0.0003 & $0.0047^{\star * *}$ & 0.0008 & $0.0038^{* * *}$ & 0.0006 \\
\hline Job tenure squared $\left(1 / 10^{2}\right)$ & $-0.0012^{\star * *}$ & 0.0002 & $-0.0017^{\star \star *}$ & 0.0006 & $-0.0012^{* * *}$ & 0.0004 \\
\hline Foreigner & 0.0104 & 0.0198 & 0.0522 & 0.0356 & $0.0505^{\star}$ & 0.0306 \\
\hline Without vocational training & $0.8617^{\star}$ & 0.5230 & $-0.0637^{\star \star \star}$ & 0.0185 & $-0.0587^{\star \star \star}$ & 0.0168 \\
\hline Graduate degree & -0.2419 & 0.2020 & $0.3162^{\star \star \star}$ & 0.0130 & $0.2901^{\star \star \star}$ & 0.0122 \\
\hline Simple blue-collar occupation & 10,861 & 0.7980 & $-0.0659 * \star *$ & 0.0307 & -0.0272 & 0.0238 \\
\hline Qualified blue-collar occupation & $2.2363^{\star \star *}$ & 0.4579 & $-0.0429 *$ & 0.0260 & -0.0258 & 0.0220 \\
\hline Engineers & $2.5088^{\star * *}$ & 0.5216 & $0.1935^{\star \star \star}$ & 0.0263 & $0.1862^{\star \star \star}$ & 0.0250 \\
\hline Clerical and administrative occupation & $1.7888^{* * *}$ & 0.4112 & $0.2001^{\star \star \star}$ & 0.0323 & $0.1685^{\star \star \star}$ & 0.0241 \\
\hline Profession, manager and others & $1.7561^{* * *}$ & 0.4345 & $0.2760 * \star \star$ & 0.0223 & $0.2742^{\star * *}$ & 0.0236 \\
\hline Employment size $\left(1 / 10^{3}\right)$ & $0.0565^{\star * *}$ & 0.0211 & & & $0.1426^{\star \star *}$ & 0.0299 \\
\hline Employment size squared $\left(1 / 10^{6}\right)$ & -0.0050 & 0.0044 & & & -0.0143 & 0.0074 \\
\hline Industry-wide wage agreement & $0.0995^{\star \star *}$ & 0.0206 & & & & \\
\hline Firm-specific wage agreement & 0.0154 & 0.0213 & & & & \\
\hline Works council & 0.1630 *** & 0.0234 & & & & \\
\hline Sales per employee $\left(1 / 10^{5}\right)$ & 0.0005 & 0.0008 & & & & \\
\hline Wage bill per employee $\left(1 / 10^{4}\right)$ & $0.9937^{\star * *}$ & 0.3406 & & & & \\
\hline Very high or high state of the technology & 0.0177 & 0.0118 & & & & \\
\hline Average weekly working hours & 0.0061 & 0.0083 & $-0.0294^{\star \star \star}$ & 0.0068 & $-0.0358^{\star \star \star}$ & 0.0063 \\
\hline Overtime & $0.0899 * *$ & 0.0414 & $0.0542^{*}$ & 0.0306 & $0.0600 * \star *$ & 0.0222 \\
\hline No overtime compensation & 0.0414 & 0.0689 & -0.0832 & 0.0688 & -0.0376 & 0.0802 \\
\hline Improving work-child compatibility & $0.0755^{\star \star \star}$ & 0.0257 & $0.1145^{\star \star \star}$ & 0.0245 & 0.0182 & 0.0193 \\
\hline Workplace health promotion & 0.0353 & 0.0408 & $0.1222^{\star \star \star}$ & 0.0273 & $0.0749^{\star \star *}$ & 0.0212 \\
\hline Workplace with physical or mental stress & 0.0438 & 0.0274 & 0.0235 & 0.0212 & 0.0051 & 0.0167 \\
\hline Workplace with high flexibility needs & 0.0237 & 0.0295 & -0.0062 & 0.0218 & -0.0047 & 0.0176 \\
\hline Region / Industry controls / Interaction terms & yes / ye & s / yes & yes / ye & es /no & yes / ye & es / no \\
\hline Log pseudolikelihood & & & $-16,88$ & 34.69 & $-9,98$ & 35.71 \\
\hline Observations & 75,3 & & 75,3 & 340 & & 340 \\
\hline
\end{tabular}

Note: The dependent variable is the log of the real daily wage. The results are based on Tobit regressions. Clustered standard errors at the establishment level. The estimated coefficients for the regional, industry controls and interaction terms are available upon request from the author.

Significance levels: *: 10 percent **:5 percent ***: 1 percent

Source: LIAB cross-sectional model 2002. 
Table A 8, continued: Estimates of Tobit wage regressions for female employees, eastern Germany

\begin{tabular}{|c|c|c|c|c|c|c|}
\hline \multirow[b]{2}{*}{ Variables } & \multicolumn{2}{|c|}{ Specification (10) } & \multicolumn{2}{|c|}{ Specification (11) } & \multicolumn{2}{|c|}{ Specification (12) } \\
\hline & Coeff. & Std. Err. & Coeff. & Std. Err. & Coeff. & Std. Err. \\
\hline Female proportion & $-0.1906^{* \star *}$ & 0.0000 & $-0.3493^{\star * *}$ & 0.0467 & $-0.3000^{\star \star *}$ & 0.0395 \\
\hline Age & $0.0392^{\star * *}$ & 0.0000 & & & & \\
\hline Age squared $\left(1 / 10^{2}\right)$ & $-0.0450^{\star \star \star}$ & 0.0000 & & & & \\
\hline Job tenure (in month) & $0.0036^{\star \star *}$ & 0.0000 & & & & \\
\hline Job tenure squared $\left(1 / 10^{2}\right)$ & $-0.0014^{\star * *}$ & 0.0000 & & & & \\
\hline Foreigner & 0.0271 & 0.2590 & & & & \\
\hline Without vocational training & $-0.0477^{\star \star \star}$ & 0.0030 & & & & \\
\hline Graduate degree & $0.2803^{\star \star *}$ & 0.0000 & & & & \\
\hline Simple blue-collar occupation & -0.0309 & 0.1300 & & & & \\
\hline Qualified blue-collar occupation & -0.0323 & 0.0890 & & & & \\
\hline Engineers & $0.1865^{\star \star \star}$ & 0.0000 & & & & \\
\hline Clerical and administrative occupation & $0.1691^{\star * *}$ & 0.0000 & & & & \\
\hline Profession, manager and others & $0.2538^{\star * *}$ & 0.0000 & & & & \\
\hline Employment size $\left(1 / 10^{3}\right)$ & $0.0736^{\star * *}$ & 0.0030 & $0.2326^{\star \star \star}$ & 0.0339 & $0.1130 * * *$ & 0.0261 \\
\hline Employment size squared $\left(1 / 10^{6}\right)$ & -0.0056 & 0.2990 & $-0.0306^{\star \star \star}$ & 0.0082 & $-0.0138^{\star \star \star}$ & 0.0052 \\
\hline Industry-wide wage agreement & $0.1209 * * *$ & 0.0000 & & & $0.1410 * \star *$ & 0.0304 \\
\hline Firm-specific wage agreement & 0.0119 & 0.6570 & & & 0.0115 & 0.0359 \\
\hline Works council & $0.2167^{\star \star \star}$ & 0.0000 & & & $0.3003^{\star \star \star}$ & 0.0289 \\
\hline \multicolumn{7}{|l|}{ Sales per employee $\left(1 / 10^{5}\right)$} \\
\hline \multicolumn{7}{|l|}{ Wage bill per employee $\left(1 / 10^{4}\right)$} \\
\hline \multicolumn{7}{|l|}{ Very high or high state of the technology } \\
\hline Average weekly working hours & $-0.0219^{\star \star \star}$ & 0.0000 & & & & \\
\hline Overtime & $0.0425^{\star \star \star}$ & 0.0130 & & & & \\
\hline No overtime compensation & 0.0518 & 0.4610 & & & & \\
\hline Improving work-child compatibility & 0.0102 & 0.5280 & & & & \\
\hline Workplace health promotion & $0.0310^{*}$ & 0.0560 & & & & \\
\hline Workplace with physical or mental stress & -0.0019 & 0.8940 & & & & \\
\hline Workplace with high flexibility needs & -0.0008 & 0.9560 & & & & \\
\hline Region / Industry controls / Interaction terms & \multicolumn{2}{|c|}{ yes / yes / no } & \multicolumn{2}{|c|}{ yes / yes / no } & \multicolumn{2}{|c|}{ yes / yes /no } \\
\hline Log pseudolikelihood & \multicolumn{2}{|c|}{$-4,616.97$} & \multicolumn{2}{|c|}{$-27,218.58$} & \multicolumn{2}{|c|}{$-20,404.96$} \\
\hline Observations & \multicolumn{2}{|c|}{75,340} & \multicolumn{2}{|c|}{75,340} & \multicolumn{2}{|c|}{75,340} \\
\hline
\end{tabular}

Note: The dependent variable is the log of the real daily wage. The results are based on Tobit regressions. Clustered standard errors at the establishment level. The estimated coefficients for the regional, industry controls and interaction terms are available upon request from the author.

Significance levels: *: 10 percent $* *: 5$ percent $* * *: 1$ percent

Source: LIAB cross-sectional model 2002. 
Table A 8, continued: Estimates of Tobit wage regressions for female employees, eastern Germany

\begin{tabular}{|c|c|c|c|}
\hline \multirow[b]{2}{*}{ Variables } & Specification (13) & \multicolumn{2}{|c|}{ Specification (14) } \\
\hline & Coeff. Std. Err. & Coeff. & Std. Err. \\
\hline Female proportion & $-0.1874^{\star \star \star} 0.0388$ & $-0.1901^{\star \star}$ & $* 0.0373$ \\
\hline \multicolumn{4}{|l|}{ Age } \\
\hline \multicolumn{4}{|l|}{ Age squared $\left(1 / 10^{2}\right)$} \\
\hline \multicolumn{4}{|l|}{ Job tenure (in month) } \\
\hline \multicolumn{4}{|l|}{ Job tenure squared $\left(1 / 10^{2}\right)$} \\
\hline \multicolumn{4}{|l|}{ Foreigner } \\
\hline \multicolumn{4}{|l|}{ Without vocational training } \\
\hline \multicolumn{4}{|l|}{ Graduate degree } \\
\hline \multicolumn{4}{|l|}{ Simple blue-collar occupation } \\
\hline \multicolumn{4}{|l|}{ Qualified blue-collar occupation } \\
\hline \multicolumn{4}{|l|}{ Engineers } \\
\hline \multicolumn{4}{|l|}{ Clerical and administrative occupation } \\
\hline \multicolumn{4}{|l|}{ Profession, manager and others } \\
\hline Employment size $\left(1 / 10^{3}\right)$ & $0.0814^{\star \star \star} 0.0224$ & $0.0810^{\star *}$ & $* 0.0227$ \\
\hline Employment size squared $\left(1 / 10^{6}\right)$ & $-0.0111^{\star \star \star} 0.0039$ & $-0.0105^{\star *}$ & $* 0.0039$ \\
\hline Industry-wide wage agreement & $0.1090^{\star \star \star} 0.0282$ & $0.1054^{\star *}$ & * 0.0269 \\
\hline Firm-specific wage agreement & $0.0142 \quad 0.0285$ & 0.0097 & 0.0269 \\
\hline Works council & $0.2229^{\star \star \star} 0.0310$ & $0.2063^{\star *}$ & * 0.0298 \\
\hline Sales per employee $\left(1 / 10^{5}\right)$ & $0.0007 \quad 0.0008$ & 0.0008 & 0.0008 \\
\hline Wage bill per employee $\left(1 / 10^{4}\right)$ & $1.3758^{\star \star \star} 0.4359$ & $1.3656^{\star \star *}$ & $* 0.4459$ \\
\hline Very high or high state of the technology & $0.0274^{*} \quad 0.0143$ & $0.0230^{*}$ & 0.0140 \\
\hline \multicolumn{2}{|l|}{ Average weekly working hours } & \multicolumn{2}{|c|}{$-0.0192^{\star \star \star} 0.0065$} \\
\hline \multicolumn{2}{|l|}{ Overtime } & 0.0381 & 0.0151 \\
\hline \multicolumn{2}{|l|}{ No overtime compensation } & 0.0199 & 0.0935 \\
\hline \multicolumn{2}{|l|}{ Improving work-child compatibility } & -0.0079 & 0.0160 \\
\hline \multicolumn{2}{|l|}{ Workplace health promotion } & 0.0127 & 0.0162 \\
\hline \multicolumn{2}{|l|}{ Workplace with physical or mental stress } & 0.0117 & 0.0158 \\
\hline \multicolumn{2}{|l|}{ Workplace with high flexibility needs } & 0.0141 & 0.0144 \\
\hline \multirow{2}{*}{\multicolumn{2}{|c|}{$\begin{array}{l}\text { Region / Industry controls / Interaction terms } \\
\text { Log pseudolikelihood }\end{array}$}} & \multicolumn{2}{|c|}{ yes / yes / no } \\
\hline & & $-16,1$ & 64.01 \\
\hline \multicolumn{2}{|l|}{ Observations } & \multicolumn{2}{|c|}{75,340} \\
\hline
\end{tabular}

Note: The dependent variable is the log of the real daily wage. The results are based on Tobit regressions. Clustered standard errors at the establishment level. The estimated coefficients for the regional, industry controls and interaction terms are available upon request from the author.

Significance levels: *: 10 percent $* *: 5$ percent $* * *: 1$ percent

Source: LIAB cross-sectional model 2002. 
Table A 9: Coefficients for the proportion of females in establishments in various specifications of a log wage equation

\begin{tabular}{|c|c|c|c|c|c|}
\hline \multirow{2}{*}{\multicolumn{2}{|c|}{ Specification }} & \multicolumn{2}{|c|}{ Western Germany } & \multicolumn{2}{|c|}{ Eastern Germany } \\
\hline & & Males & Females & Males & Females \\
\hline \multirow[t]{2}{*}{ (1) } & proportion of females & $0.1071^{\star * *}$ & $-0.2316^{\star \star \star}$ & $0.1717^{\star \star \star}$ & -0.0099 \\
\hline & & $(0.0368)$ & $(0.0298)$ & $(0.0567)$ & $(0.0567)$ \\
\hline \multirow[t]{2}{*}{ (2) } & (1) + human capital + occupation & $-0.2082^{\star \star \star}$ & $-0.2669 * \star \star$ & $-0.0889 *$ & -0.0819 \\
\hline & + regions & $(0.0241)$ & $(0.0254)$ & $(0.0458)$ & $(0.0556)$ \\
\hline \multirow[t]{2}{*}{ (8) } & (2) + workplace characteristics & $-0.1553^{\star \star \star}$ & $-0.1810 * \star \star$ & $-0.0675^{\star}$ & -0.0442 \\
\hline & & $(0.0169)$ & $(0.0215)$ & $(0.0414)$ & $(0.0462)$ \\
\hline \multirow[t]{2}{*}{ (9) } & (8) + establishment size + industry & $-0.1549 * \star \star$ & $-0.1896^{\star \star \star}$ & $-0.1354^{\star \star \star}$ & $-0.2231^{\star \star *}$ \\
\hline & & $(0.0199)$ & $(0.0257)$ & $(0.0324)$ & $(0.0387)$ \\
\hline \multirow[t]{2}{*}{ (10) } & (9) + institutional setting & $-0.1555^{\star \star \star}$ & $-0.1669 * \star \star$ & $-0.1296^{\star \star \star}$ & $-0.1906^{\star * *}$ \\
\hline & & $(0.0195)$ & $(0.0252)$ & $(0.0318)$ & $(0.0334)$ \\
\hline \multirow[t]{2}{*}{ (5) } & $(10)+$ achievement potential & $-0.0793^{\star \star \star}$ & $-0.0462^{\star *}$ & $-0.0728^{\star \star}$ & $-0.1203^{\star * *}$ \\
\hline & & $(0.0188)$ & $(0.0225)$ & $(0.0345)$ & $(0.0321)$ \\
\hline \multicolumn{2}{|c|}{ Number of observations } & 565,100 & 192,814 & 120,985 & 75,340 \\
\hline
\end{tabular}

Note: The dependent variable is the log of the real daily wage. The results are based on Tobit regressions. Standard errors are in parentheses and are adjusted for clustering at the establishment level. The complete estimation results are in Tables C5 - C8. Significance levels: *: 10 percent **:5 percent ***: 1 percent Source: own calculation, LIAB cross-sectional model 2002.

Table A 10: Coefficients for the proportion of females in establishments in various specifications of a log wage equation without controlling for individual productivity-related characteristics

\begin{tabular}{|c|c|c|c|c|c|}
\hline \multirow{2}{*}{\multicolumn{2}{|c|}{ Specification }} & \multicolumn{2}{|c|}{ Western Germany } & \multicolumn{2}{|c|}{ Eastern Germany } \\
\hline & & Males & Females & Males & Females \\
\hline (1) & proportion of females & $\begin{array}{l}0.1071 \text { *** } \\
(0.0368)\end{array}$ & $\begin{array}{l}-0.2316^{\star \star \star} \\
(0.0298)\end{array}$ & $\begin{array}{l}0.1717^{\star \star \star} \\
(0.0567)\end{array}$ & $\begin{array}{l}-0.0099 \\
\quad(0.0567)\end{array}$ \\
\hline (11) & $(1)+$ establishment size + industry & $\begin{array}{l}0.0717^{\star \star \star} \\
(0.0301)\end{array}$ & $\begin{array}{r}-0.3069^{\star \star \star} \\
(0.0333)\end{array}$ & $\begin{array}{l}-0.0054 \\
\quad(0.0424)\end{array}$ & $\begin{array}{r}-0.3493^{\star \star \star} \\
(0.0467)\end{array}$ \\
\hline (12) & $(11)+$ institutional setting & $\begin{array}{l}0.0671^{\star *} \\
(0.0302)\end{array}$ & $\begin{array}{l}-0.2656^{\star \star \star} \\
(0.0314)\end{array}$ & $\begin{array}{l}0.0109 \\
\quad(0.0418)\end{array}$ & $\begin{array}{l}-0.3000^{* \star *} \\
(0.0395)\end{array}$ \\
\hline (13) & $(12)+$ achievement potential & $\begin{array}{l}0.1829^{\star \star \star} \\
(0.0241)\end{array}$ & $\begin{array}{r}-0.0825^{\star \star \star} \\
(0.0290)\end{array}$ & $\begin{array}{l}0.0889^{* *} \\
(0.0434)\end{array}$ & $\begin{array}{l}-0.1874^{\star \star *} \\
(0.0388)\end{array}$ \\
\hline (14) & $(13)+$ workplace characteristics & $\begin{array}{l}0.1767^{\star \star \star} \\
(0.0236)\end{array}$ & $\begin{array}{r}-0.0816^{\star \star \star} \\
(0.0286)\end{array}$ & $\begin{array}{l}0.0804^{*} \\
(0.0427)\end{array}$ & $\begin{array}{r}-0.1901^{\star \star \star} \\
(0.0373)\end{array}$ \\
\hline Num & er of observations & 565,100 & 192,814 & 120,985 & 75,340 \\
\hline
\end{tabular}

Note: The dependent variable is the log of the real daily wage. The results are based on Tobit regressions. Standard errors are in parentheses and are adjusted for clustering at the establishment level. The complete estimation results are in Tables C5 - C8. Significance levels: *: 10 percent **:5 percent ***: 1 percent Source: own calculation, LIAB cross-sectional model 2002. 


\section{References}

Achatz, J., H. Gartner and T. Glück (2005): “Bonus oder Bias? Mechanismen geschlechtsspezifischer Entlohnung“, Kölner Zeitschrift für Soziologie und Sozialpsychologie, 57(3), 466-493.

Altonji, J. G. and R. M. Blank (1999): "Race and Gender in the Labor Market”, in O. Ashenfelter and D. Card (Eds.), Handbook of Labor Economics, Vol. 3(3), chap.48 48, 3143-3259, Elsevier: Amsterdam.

Amuedo-Dorantes, C. and S. De la Rica (2006): “The Role of Segregation and Pay Structure on the Gender Wage Gap: Evidence from Matched Employer-Employee Data for Spain”, Contributions to Economic Analysis \& Policy, 5(1), 1-32.

Arrow, K. J. (1973): “The Theory of Discrimination”, in: O. C. Ashenfelter and A. Rees (eds.), Discrimination in Labor Markets, 3-33, Princeton University Press: New Jersey.

Bayard, K., J. Hellerstein, D. Neumark and K. Troske (2003): "New Evidence on Sex Segregation and Sex Differences in Wages from Matched Employee-Employer Data”, Journal of Labor Economics, 21(4) 887 - 922.

Becker, G. S. (1971): “The Economics of Discrimination”, $2^{\text {nd }}$ ed., University of Chicago Press: Chicago.

Bender, S., Haas, A. and C. Klose (2000): “IAB Employment Subsample 1975-1995. Opportunities for Analysis Provided by the Anonymised Subsample”,IZA Discussion Paper 117, Institute for the Study of Labor (IZA), Bonn.

Bergmann, B. R. (1974): “Occupational Segregation, Wages and Profits When Employers Discriminate by Race or Sex”, Eastern Economic Journal, 1(2), 103-110.

Blau, F. D. (1977): "Equal Pay in the Office”, Lexington Books: Lexington, Massachusetts

Buckley, J. E. (1971): “Pay Differences Between Men and Women in the Same Job”, Monthly Labor Review, 94(11) 36-39.

Burdett, K. and D. T. Mortensen (1998): "Wage Differentials, Employer Size, and Unemployment”, International Economic Review, 39(2), 257-273.

Carrington, W. J. and K. R. Troske (1995): "Gender Segregation in Small Firms", The Journal of Human Resources, 30(3), 503-533.

Carrington, W. J. and K. R. Troske (1998): "Sex Segregation in US Manufacturing”, Industrial and Labor Relations Review, 51(3), 445 - 464.

Datta Gupta, N. and D. S. Rothstein (2005): “The Impact of Worker and Establishment-Level Characteristics on Male-Female Wage Differentials: Evidence from Danish Matched Employee-Employer Data”, LABOUR: Review of Labour Economics \& Industrial Relations, 19(1), 1 - 34.

Fields, J. and E. N. Wolff (1995): "Interindustry Wage Differentials and the Gender Wage Gap”, Industrial and Labor Relations Review, 49(1), 105-120.

Fitzenberger, B., A. Osikominu and R. Völter (2006): "Imputation Rules to Improve the Education Variable in the IAB Employment Subsample", Schmollers Jahrbuch, 126(3) 405-436.

Foguel, M. N. (2004): "The Effects of Gender Segregation at the Establishment Level on Wages: An Empirical Analysis Using a Panel of Matched Employer-Employee Data”, unpublished manuscript. 
Groshen, E. L. (1991a): “The Structure of the Female/Male Wage Differential: Is It Who You Are, What You Do, or Where You Work?”, Journal of Human Resources, 26(3), 457472.

Hirsch, B. T. and D. A. Macpherson (2004): "Wages, Sorting on Skill, and the Racial Composition of Jobs”, Journal of Labor Economics, 22(1), 189-210.

Hirsch, B. T. and E. J. Schumacher (1992): "Labor Earnings, Discrimination, and the Racial Composition of Jobs”, Journal of Human Resources, 27(4), 602-628.

Hirsch, B., T. Schank and C. Schnabel (2006): "Gender Differences in Labor Supply to Monopsonistic Firms: An Empirical Analysis Using Linked Employer-Employee Data from Germany” IZA Discussion Paper 2443, Institute for the Study of Labor (IZA), Bonn.

Hunt, J. (2002): "The Transition in East Germany: "When is a Ten-Point Fall in the Gender Wage Gap Bad News”, Journal of Labor Economics, 20(1), 148-169.

Jurajda, S. and H. Harmgart (2007): “When are 'Female' Occupations Paying More?”, Journal of Comparative Economics, 35 (1), 170-187.

Kölling, A. (2000): “The IAB Establishment Panel”, Schmollers Jahrbuch, 120(2): 291-300.

Macpherson, D. A. and B. T. Hirsch (1995): "Wages and Gender Composition: Why Do Women’s Jobs Pay Less?”, Journal of Labor Economics, 13(3) 426-471.

Manning, A. (1994): “Labor Markets with Company Wage Policies”, CEP Discussion Paper 214, Centre for Economic Performance (CEP), London.

Manning, A. (2003): "Monopsony in Motion: Imperfect Competition in Labor Markets", Princeton University Press: New Jersey.

McNulty, D. J. (1967): “Differences in Pay Between Men and Women Workers”, Monthly Labor Review, 90(12): 40-43.

Mincer, J. and S. Polachek (1974): "Family Investments in Human Capital: Earnings of Women”, Journal of Political Economy, Vol. 82(2), S76-S108.

Polachek, S. W. (1979): “Occupational Segregation Among Women: Theory, Evidence and a Prognosis”, in: C. B. Lloyd, E. S. Andrews, and C. L. Gilroy (eds.), Women in the Labor Market, Columbia University Press: New York.

Polachek, S. W. (1981): “Occupational Self-Selection: A Human Capital Approach to Sex Differences in Occupational Structure”, Review of Economics and Statistics, 63(1): 6069.

Ransom, M. R. and R. L. Oaxaca (2005): Sex Differences in Pay in a "New Monopsony" Model of the Labor Market, IZA Discussion Paper 1870, Institute for the Study of Labor (IZA), Bonn.

Reilly, K. T. and T. S. Wirjanto (1999a): "Does More Mean Less? The Male/Female Wage Gap and the Proportion of Females at the Establishment Level”, Canadian Journal of Economics, 32(4): 906-929.

Reilly, K. T. and T. S. Wirjanto (1999b): "The Proportion of Females in the Establishment: Discrimination, Preferences and Technology”, Canadian Public Policy, 25(S1), S73S94.

Robinson, J. M. (1933): “The Economics of Imperfect Competition”, Palgrave Macmillan: London.

Rosen, S. (1986): "The Theory of Equalizing Differences", in: O. C. Ashenfelter and R. Layard (eds.), Handbook of Labor Economics, Vol. 1 (3), chapt. 12, 641-692, Elsevier: 
Amsterdam.

Vieira, J. A. C., A. R. Cardoso and M. Portela (2005): Gender Segregation and the Wage Gap in Portugal: An Analysis at the Establishment Level, Journal of Economic Inequality, Vol. 3, No.2: 145-168. 